\begin{tabular}{|c|c|}
\hline Title & $\begin{array}{l}\text { Southern Hemisphere A dditional Ozonesondes (SHA DOZ) 1998-2000 tropical ozone climatology 1. Comparison with } \\
\text { Total Ozone Mapping Spectrometer (TOMS) and ground-based measurements }\end{array}$ \\
\hline Author(s) & $\begin{array}{l}\text { Thompson, A nne M.; Witte, Jacquelyn C.; McPeters, Richard D.; Oltmans, Samuel J.; Schmidlin, Francis J.; Logan, } \\
\text { Jennifer A.; Fujiwara, Masatomo; Kirchhoff, V olker W W. J. H.; Posny, Franc, oise; Coetzee, Gert J. R.; Hoegger, Bruno; } \\
\text { Kawakami, Shuji; Ogawa, Toshihiro; Johnson, Bryan J.; V Vomel, Holger; Labow, Gordon }\end{array}$ \\
\hline Citation & $\begin{array}{l}\text { Journal of Geophysical Research A tmospheres, 108(D2), PEM 10-1-PEM 10-19 } \\
\text { https://doi.org/10.1029/2001DD000967 }\end{array}$ \\
\hline Issue Date & 2003-01-27 \\
\hline Doc URL & http:/hdl.handle.net/2115/64851 \\
\hline Rights & Copyright 2003 A merican Geophysical Union. \\
\hline Type & article \\
\hline File Information & Thompson_et_al-2003-Journal_of_Geophysical_Research_A tmospheres_(1984 2012).pdf \\
\hline
\end{tabular}

Instructions for use 


\section{Southern Hemisphere Additional Ozonesondes (SHADOZ) 1998-2000 tropical ozone climatology \\ 1. Comparison with Total Ozone Mapping Spectrometer (TOMS) and ground-based measurements}

Anne M. Thompson, ${ }^{1}$ Jacquelyn C. Witte, ${ }^{1,2}$ Richard D. McPeters, ${ }^{1}$ Samuel J. Oltmans, ${ }^{3}$ Francis J. Schmidlin, ${ }^{4}$ Jennifer A. Logan, ${ }^{5}$ Masatomo Fujiwara, ${ }^{6}$

Volker W. J. H. Kirchhoff, ${ }^{7}$ Françoise Posny, ${ }^{8}$ Gert J. R. Coetzee, ${ }^{9}$ Bruno Hoegger, ${ }^{10}$ Shuji Kawakami, ${ }^{11}$ Toshihiro Ogawa, ${ }^{11}$ Bryan J. Johnson, ${ }^{3}$ Holger Vömel, ${ }^{3}$ and Gordon Labow ${ }^{1,2}$

Received 13 June 2001; revised 27 December 2001; accepted 31 December 2001; published 30 January 2003.

[1] A network of 10 southern hemisphere tropical and subtropical stations, designated the Southern Hemisphere Additional Ozonesondes (SHADOZ) project and established from operational sites, provided over 1000 ozone profiles during the period 1998-2000.

Balloon-borne electrochemical concentration cell (ECC) ozonesondes, combined with standard radiosondes for pressure, temperature, and relative humidity measurements, collected profiles in the troposphere and lower to midstratosphere at: Ascension Island; Nairobi, Kenya; Irene, South Africa; Réunion Island; Watukosek, Java; Fiji; Tahiti; American Samoa; San Cristóbal, Galapagos; and Natal, Brazil. The archived data are available at: $\langle\mathrm{http}: / / \mathrm{croc}$.gsfc.nasa.gov/shadoz $\rangle$. In this paper, uncertainties and accuracies within the SHADOZ ozone data set are evaluated by analyzing: (1) imprecisions in profiles and in methods of extrapolating ozone above balloon burst; (2) comparisons of column-integrated total ozone from sondes with total ozone from the Earth-Probe/Total Ozone Mapping Spectrometer (TOMS) satellite and ground-based instruments; and (3) possible biases from station to station due to variations in ozonesonde characteristics. The key results are the following: (1) Ozonesonde precision is 5\%. (2) Integrated total ozone column amounts from the sondes are usually to within $5 \%$ of independent measurements from ground-based instruments at five SHADOZ sites and overpass measurements from the TOMS satellite (version 7 data). (3) Systematic variations in TOMS-sonde offsets and in ground-based-sonde offsets from station to station reflect biases in sonde technique as well as in satellite retrieval. Discrepancies are present in both stratospheric and tropospheric ozone. (4) There is evidence for a zonal wave-one pattern in total and tropospheric ozone, but not in stratospheric ozone. INDEX TERMS: 0394 Atmospheric Composition and Structure: Instruments and techniques; 3309 Meteorology and Atmospheric Dynamics: Climatology (1620); 9305 Information Related to Geographic Region: Africa; 9325 Information Related to Geographic Region: Atlantic Ocean; 9340 Information Related to Geographic Region: Indian Ocean; 9355 Information Related to Geographic Region: Pacific Ocean; 3394 Meteorology and Atmospheric Dynamics: Instruments and techniques; 1640 Global Change: Remote sensing; KEYWORDS: Ozone,

Ozonesondes, Satellite ozone, Tropical climatology

Citation: Thompson, A. M., et al., Southern Hemisphere Additional Ozonesondes (SHADOZ) 1998-2000 tropical ozone climatology, 1, Comparison with Total Ozone Mapping Spectrometer (TOMS) and ground-based measurements, J. Geophys. Res., 108(D2), 8238, doi:10.1029/2001JD000967, 2003.

\footnotetext{
${ }^{1}$ NASA Goddard Space Flight Center, Greenbelt, Maryland, USA. USA.

${ }^{2}$ Also at Science Systems and Applications, Inc., Lanham, Maryland,

${ }^{3}$ NOAA Climate Monitoring and Diagnostics Laboratory, Boulder, Colorado, USA

${ }^{4}$ NASA Wallops Flight Facility, Wallops Island, Virginia, USA.

Copyright 2003 by the American Geophysical Union. 0148-0227/03/2001JD000967
}

\footnotetext{
${ }^{5}$ Department of Earth and Planetary Sciences, Harvard University, Cambridge, Massachusetts, USA.

${ }^{6}$ Radio Science Center for Space and Atmosphere, Kyoto University, Kyoto, Japan.

${ }^{7}$ INPE Laboratorio Ozonio, São José dos Campos, Brazil.

${ }^{8}$ Université de la Réunion, St.-Denis, Réunion, France.

${ }^{9}$ South African Weather Service, Pretoria, South Africa.

${ }^{10}$ Swiss Aerological Observatory, Payerne, Switzerland.

${ }^{11}$ NASDA Earth Observations Research Center, Tokyo, Japan.
} 


\section{Introduction: Background for SHADOZ}

\subsection{Requirements for Tropical Ozone Profiles}

[2] Balloon-borne ozonesondes play an essential role in monitoring stratospheric and tropospheric ozone [Logan, 1994; World Meteorological Organization (WMO), 1998a], preparing climatologies [Logan, 1999a, 1999b], developing satellite retrieval algorithms [Bhartia et al., 1996; Chance et al., 1996; Burrows et al., 1999], and for evaluating the accuracy of space-borne instruments, satellite data products and model calculations of ozone. During the 1990's at least a dozen southern hemisphere tropical and subtropical stations flew ozonesondes but sampling was often sporadic and geographical coverage uneven.

[3] For example, during SAFARI/TRACE-A (Southern African Fire Atmospheric Research Initiative/Transport and Atmospheric Chemistry near the Equator-Atlantic) more than fifty soundings were taken at five sites for a 6-week period in 1992 [Diab et al., 1996; Kirchhoff et al., 1996; Nganga et al., 1996; Thompson et al., 1996a]. By the end of 1993 only one of these stations remained operational. Three Pacific sites (American Samoa, Tahiti, Fiji) launched ozonesondes in conjunction with PEM-Tropics, 1966-1999 (Pacific Exploratory Mission [Oltmans et al., 2001]). Two others (Christmas Island; San Cristóbal, Galapagos) started during SOWER (1998-1999; Soundings of Ozone and Water in the Equatorial Region [Hasebe et al., 2000]). Soundings began in 1992-1993 in the western Indian Ocean (Réunion Island; Baldy et al., 1996; Taupin et al., 1999; Randriambelo et al., 2000) and over Indonesia [Komala et al., 1996; Fujiwara et al., 2000]. Natal, Brazil $(6 \mathrm{~S}, 35 \mathrm{~W})$ is the only tropical ozonesonde station that has operated continuously since the late 1970's [Logan and Kirchhoff, 1986; Kirchhoff et al., 1988, 1991].

[4] Gaps in ozonesonde operations limit the profile database for satellite algorithm and trends research in the tropics. Ozone changes are expected as a consequence of economic growth and land-use and forestry/vegetation changes. In-situ ozone data that can resolve features in tropical ozone variability related to climate and dynamics, e.g. the Quasi-Biennial Oscillation (QBO), El Niño-Southern Oscillation (ENSO) and the zonal wave-one feature seen in satellite ozone [Shiotani, 1992; Shiotani and Hasebe, 1994], are limited to a few stations. New retrievals of satellite tropospheric ozone have increased the demand for tropical ozonesonde data for validation [Fishman and Brackett, 1997; Ziemke et al., 1998; Thompson and Hudson, 1999; Thompson et al., 2001]. A proliferation of global chemical-transport models for interpreting satellite data and predicting future ozone highlights the sparseness of tropical ozone profiles for evaluation of model simulations.

\subsection{Initiation of SHADOZ: Station Selection}

[5] The SHADOZ project was initiated to remedy the lack of consistent tropical ozonesonde observations through the augmentation of ozone balloon launches at operational sites (section 2). One guiding principle of SHADOZ is the enhancement of sonde launches at existing facilities on a cost-share basis with international partners. A second criterion is a zonal distribution of sites suitable for studying the wave-one pattern that has been observed in equatorial total ozone [Shiotani, 1992; Kim et al., 1996; Ziemke et al., 1996; Hudson and Thompson, 1998]. The SHADOZ archive includes four Pacific islands: Fiji, Tahiti, San Cristóbal (Galapagos) and American Samoa. Two sites are in the Atlantic region: Natal (Brazil) and Ascension Island. Four other sites span the region from Africa across the Indian Ocean and maritime continent (Nairobi; Irene, near Pretoria, South Africa; Réunion Island; Watukosek, Java, Indonesia). Location coordinates appear in Table 1.

[6] A third principle of SHADOZ site selection is a commitment to public, rapid distribution of the data in a central archive. This is based on assumptions that: (1) wide dissemination and interaction among sonde data users will leverage local funding to maintain infrastructure and operations; (2) evaluation of the data by users will assist in quality assurance and support correlative ozone measurements. From time to time, ozonesonde data from intensive campaigns at other tropical locations are archived in SHADOZ. Campaigns may also lead to more concentrated launches at the regular SHADOZ stations.

\subsection{Scope of Paper}

[7] At the end of 2000, over 1000 ozone, temperature and relative humidity profiles had been archived at the SHADOZ website 〈http://croc.gsfc.nasa.gov/shadoz $\rangle$. The 1998-2000 data have been transmitted to the World Ozone and Ultraviolet Data Center (WOUDC) in Toronto /http:// msc-smc.ec.gc.ca $\rangle$ to further enhance unrestricted distribution of data. The present paper is an introduction to SHADOZ with several goals:

1. Publicize the data set to a wider set of potential users, including atmospheric chemists, tropical climatologists, meteorologists, and satellite remote sensing specialists.

2. Evaluate the precision (section 3) and accuracy (section 4) of the SHADOZ ozonesondes through analysis of profile statistics and comparison of sonde-derived column ozone amounts with ground-based and satellite ozone data. In turn, use the sondes to detect biases and possible inaccuracies in satellite measurements of total and upper stratospheric ozone.

3. Describe technical variations among stations in the ozone, temperature and humidity data (Appendix A). Even though the same basic instrument is employed at all sites, differences in ozonesonde technique among the stations affect certain uses of the data.

[8] Although all ECC (electrochemical concentration cell) techniques currently used in SHADOZ were evaluated recently in laboratory chamber experiments $[W M O, 1998 \mathrm{~b}$; Johnson et al., 2002] (H. Smit, personal communication, 2000), these tests represent half a dozen simulated flights with idealized profiles. The SHADOZ data set allows us to evaluate instrument performance and technical bias (sections 3, 4, and 5) with better statistics and under tropical operating conditions.

\section{Experimental Summary and SHADOZ Archive}

\subsection{Regular SHADOZ Sites}

[9] Table 1 lists the SHADOZ Coinvestigator responsible for each site. Note that data from two stations affiliating with SHADOZ in 2001 (Paramaribo and Malindi) are not included in the present analysis. Figure 1 shows a map similar to the one on the SHADOZ website. The nominal 
Table 1. SHADOZ Sites and Coinvestigators ${ }^{\mathrm{a}}$

\begin{tabular}{lccc}
\hline \multicolumn{1}{c}{ SHADOZ Sites } & Latitude, $^{\circ}$ & Longitude, $^{\circ}$ & Coinvestigators \\
\hline Pago Pago, Am. Samoa & -14.23 & -170.56 & Samuel Oltmans (NOAA/CMDL) \\
Papeete, Tahiti & -18.00 & -149.00 & Samuel Oltmans (NOAA/CMDL) \\
San Cristóbal, Galapagos & -0.92 & -89.60 & Samuel Oltmans (NOAA/CMDL) \\
Natal, Brazil & -5.42 & -35.38 & Volker Kirchhoff (INPE) \\
Ascension Island & -7.98 & -14.42 & Francis Schmidlin (NASA/WFF) \\
Irene, South Africa & -25.25 & 28.22 & Gert Coetzee (SAWS) \\
Nairobi, Kenya & -1.27 & 36.80 & Bruno Hoegger (Méteo-Suisse) \\
La Réunion & -21.06 & 55.48 & Françoise Posny (Univ. Réunion) \\
Watukosek, Indonesia & -7.57 & 112.65 & Toshihiro Ogawa (NASDA/EORC) \\
Suva, Fiji & -18.13 & 178.40 & Samuel Oltmans (NOAA/CMDL) \\
Paramaribo, Surinam & 5.81 & 55.21 & Hennie Kelder (KNMI) \\
Malindi, Kenya & 2.99 & 40.19 & Giovanni Laneve (Univ. Rome) \\
\hline \multicolumn{2}{c}{ a Station operators and detailed procedures appear in Appendix A }
\end{tabular}

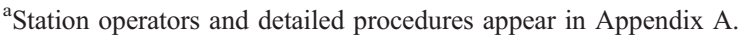

sampling schedule at all stations is once-per-week, usually but not always, midweek. Balloon-borne ozonesondes are coupled with a standard radiosonde for data telemetry transmitting air pressure, air and pump temperatures, relative humidity, and ozone to a ground receiving station. Some of the ground receiving stations also track and record wind speed and direction using GPS, although these are not archived at the SHADOZ website. ECC sondes [Komhyr, 1967, 1986; Komhyr et al., 1995] are used at all SHADOZ sites with the exception of Watukosek, Java, where prior to August 1999, MEISEI sondes were used [Kobayashi and Toyama, 1966; Komala et al., 1996; Fujiwara et al., 2000]. Appendix A summarizes the station personnel, ECC technique and radiosonde type at each station.

\subsubsection{Ozone}

[10] Figure 2 gives an example of a typical sounding as it appears in the archive. Although the SHADOZ project archives data in a uniform format, the initial analysis and calibration of data are done by the station Coinvestigator, who may reprocess at any time: updates are given on the Website. Some sites report data every $10 \mathrm{~s}$ during a flight, whereas other profiles are archived with 1-s frequency. Differences in data processing, as well as in sonde preparation, may contribute to systematic variations among some of the sites (Appendix A, section 5) [see Johnson et al., 2002].

[11] In two respects, sonde total ozone for each SHADOZ data record (Figure 1) is uniform. First, no normalization is made to total ozone from another instrument, such as a satellite or a colocated ground-based total ozone sensor. Second, data from $7 \mathrm{hPa}$ or balloon burst altitude, whichever is lower, is the uppermost data point used in computing integrated ozone. "Evaluated ozone residual" in the SHADOZ record is based on the extrapolation to the top of the atmosphere using the SBUV satellite climatology of McPeters et al. [1997]. Extrapolation by assuming a constant mixing ratio (CMR) for ozone above balloon burst is a standard technique that is useful for some diagnostic purposes. However, it introduces errors in the total ozone calculation, e.g. $>20 \%$ when a burst occurs near the ozone maximum. In $1998-2000,75 \%$ of SHADOZ launches reached $7 \mathrm{hPa}$, with eight stations having $60 \%$ or more of samples making this mark. For the other stations, good statistics (sections 3, 4, and 5) are obtained by using profiles up to $10 \mathrm{hPa}$. The header used for each SHADOZ data record includes integrated ozone from the sonde, the extrapolation "residual amount" and a TOMS overpass total ozone reading (from Level 2, version 7 data). The TOMS overpass value is taken from the orbit that passes most closely to the station and corresponds to approximately local noon. Most stations launch between 0700 and 1000 $\mathrm{h}$ local time, so the satellite and sonde measurements are well-matched. Data from SHADOZ stations maintained at other archives may differ from SHADOZ in format, integration and extrapolation.

\subsubsection{Temperature and Humidity Measurements}

[12] Pressure, temperature and humidity are provided for each ozone sounding by a meteorological radiosonde interfaced with the ozonesonde sensor and pump. Radiosondes produced by three manufacturers have been used at the SHADOZ sites (see Appendix A), with seven sites of the ten using the Vaisala sonde. Temperature is measured quite accurately with all types of radiosondes (within $0.5^{\circ} \mathrm{C}$ ). Humidity, on the other hand, is measured with less accuracy that is highly dependent on the ambient air temperature. Errors become large at air temperatures colder than $-40^{\circ} \mathrm{C}$ and should be ignored at temperatures colder than $-60^{\circ} \mathrm{C}$ or at any altitude in the stratosphere.

\subsection{Additional SHADOZ Data Sets}

[13] Table 2 lists data from campaigns that are archived in SHADOZ. Fifty-four sondes were launched at the Kaashidhoo Observatory at Malé in the Maldives as part of INDOEX (Indian Ocean Experiment [Lelieveld et al., 2001]) in January through March 1999. SHADOZ also includes sondes taken during the same period under SOWER (Soundings of Ozone and Water in the Equatorial Region) at San Cristóbal and Christmas Island in the Pacific $(2 \mathrm{~N}, 157.5 \mathrm{~W})$ [Hasebe et al., 2001]. A third augmentation of SHADOZ data is from the Aerosols99 cruise aboard the

\section{SHADOZ Sites}

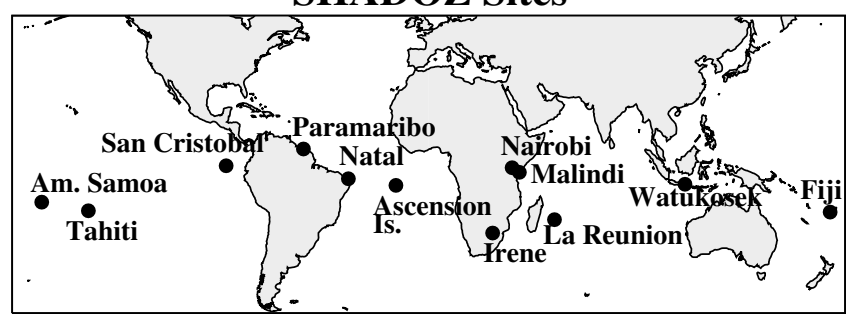

Figure 1. SHADOZ sites. Station latitude-longitude information is in Table 1. 


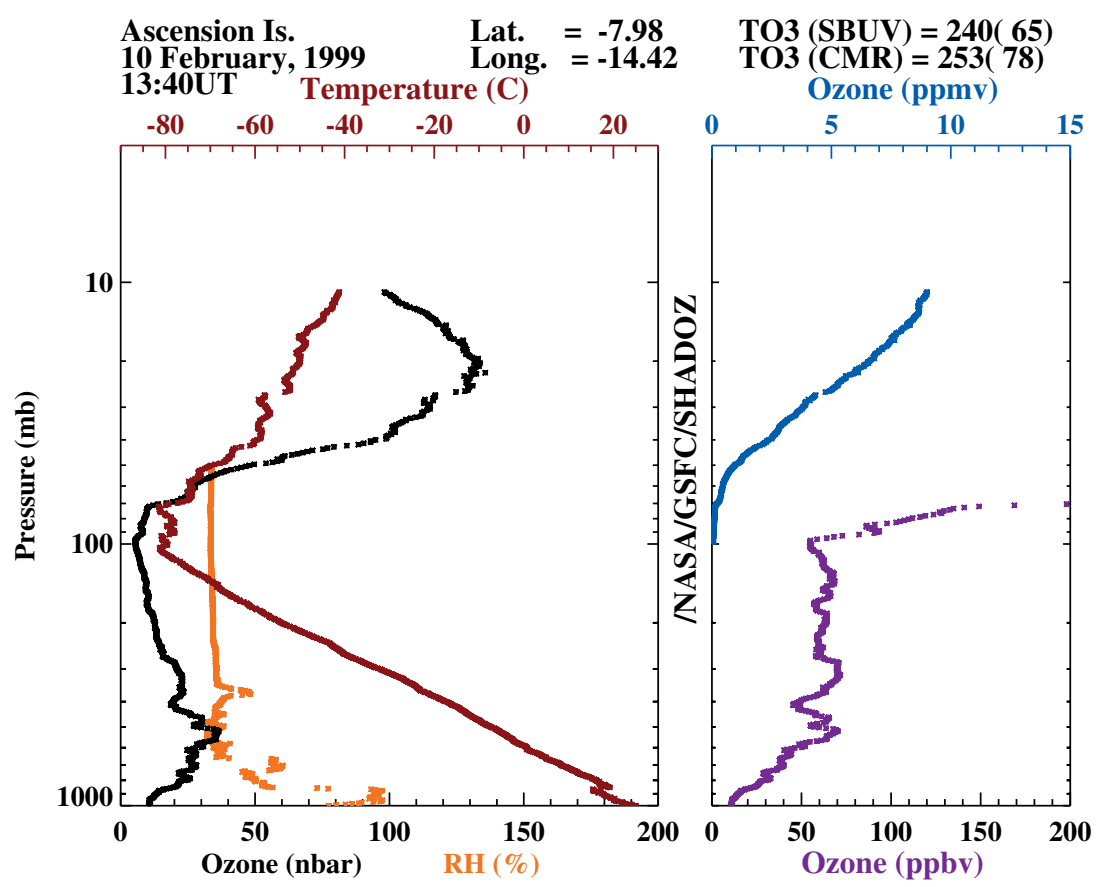

Figure 2. Typical profile from the website showing data in partial pressure (ozone, on left), relative humidity and temperature from radiosonde (also left), with ozone volume mixing ratio on right panel. Example is for an Ascension Island sounding on 10 February 1999. Reliability of humidity data above $500 \mathrm{hPa}$ is highly variable station-to-station. Generally, images in the SHADOZ archive do not display useful data above $50 \mathrm{hPa}$.

R/V Ronald H. Brown, on which 27 sondes were launched from Norfolk, Virginia, via Cape Town, South Africa, to Port-Louis, Mauritius, in January and February 1999 [Thompson et al., 2000].

\section{Sources of Uncertainties and Precision Estimates Using SHADOZ Ozone Data}

[14] Appendix A describes the theory and sources of error and uncertainty in the ECC ozonesonde measurements, but there is no easy way to evaluate the accuracy or precision of the SHADOZ data as a whole. First, each sonde launched is a new instrument. Second, differences in technique among SHADOZ sites (Appendix A and section 5) mean the data may not be strictly comparable from station to station. Systematic errors affect trend evaluation when sonde methods are changed at an individual station. Third, variations in technique complicate comparisons with independent ozone measurements from satellite, ground-based or airborne instruments and comparison among stations, e.g. in evaluating the wave-one zonal ozone pattern. If satellite-derived total ozone is used as a well-calibrated reference, the goal of using the sondes to evaluate the satellite algorithm is compromised. Nonetheless, in sections 4 and 5, we will show that by examining column ozone measurements from colocated ground-based instruments, TOMS and the SHADOZ data, it is possible to make some concrete statements about accuracy and possible systematic differences among SHADOZ stations.

[15] In this section, the precision of the ozone sounding is estimated. First, the impact of extrapolation of ozone above the balloon burst altitude is considered because this is a source of uncertainty. Second, we estimate the precision of a single instrument by examining statistics for a short timeseries of integrated ozone column amounts during campaigns in which stratospheric column ozone is expected to be nearly constant.

\subsection{Upper Stratosphere Extrapolation}

[16] Data from INDOEX-Kaashidhoo (5N, 73E; late January-late March 1999) and Aerosols99 (late JanuaryFebruary 1999) are used to estimate precision. Averaged profiles (with $1 \sigma$, shaded) for the two campaigns appear in Figure 3. Extrapolations based on constant mixing ratio (CMR) are also illustrated. Although CMR overestimates the above-burst ozone, it allows us to use information from actual profiles in the estimate of upper-stratospheric ozone. For example, the Kaashidhoo mean (Figure 3a), based on the 41 soundings that reached $7.0 \mathrm{hPa}$, aligns most closely with 10 ppmv CMR curve; this translates into an extrapo-

Table 2. Other Data Sets in the SHADOZ Archive

\begin{tabular}{lccc}
\hline \multicolumn{1}{c}{ Site/Campaign } & Latitude/Longitude & Responsible PI/Reference & Dates \\
\hline INDOEX, Kaashidhoo & $5 \mathrm{~N}, 73 \mathrm{E}$ & S. J. Oltmans & January-March 1999 \\
SOWER-Christmas Is. & $2.0 \mathrm{~N}, 157.5 \mathrm{~W}$ & Hasebe et al. $[2000]$ & March-April 1999 \\
Aerosols99 Cruise & $31 \mathrm{~N}-30 \mathrm{~S}$ & Thompson et al. $[2000]$ & January-February 1999 \\
SAFARI-2000, Zambia & $15.55,28 \mathrm{~F}$ & Thompson et al. $[2002]$ & September 2000 \\
\hline
\end{tabular}



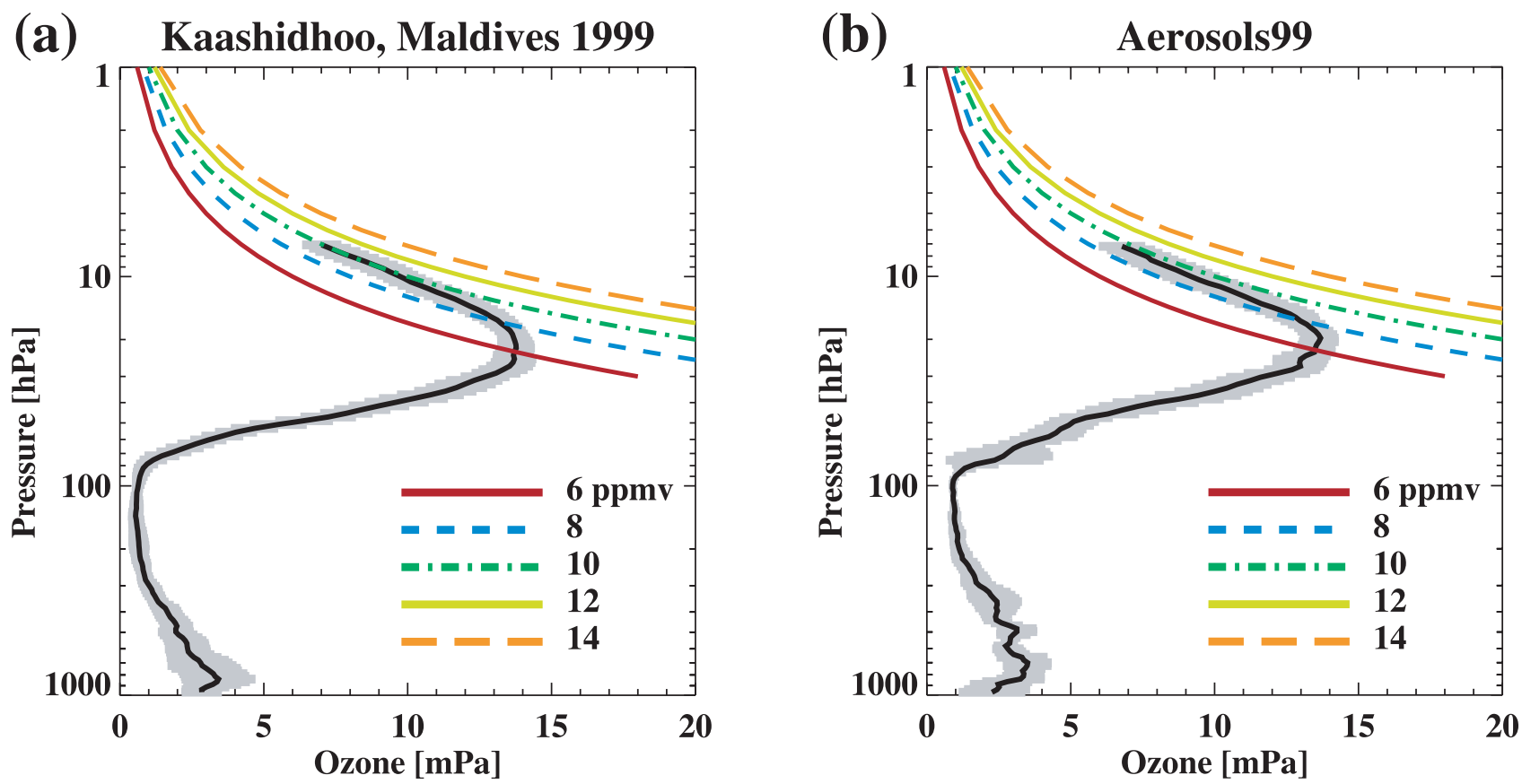

Figure 3. The mean profile from soundings during two campaigns that reached $7.0 \mathrm{hPa}$ with the $1 \sigma$ standard deviation based on $0.25 \mathrm{~km}$ averages. (A) Kaashidhoo (5N, 74E) during INDOEX (JanuaryMarch 1999); (B) Aerosols99 cruise (January-February 1999 in tropical Atlantic). Constant-mixing ratio (CMR) isolines are illustrated. Definitions of CMR vary slightly in numerical formulation and in the degree of averaging near burst. In our analysis, the uppermost points before $7 \mathrm{hPa}$ are used with a formulation that adds a column amount up to $1 \mathrm{hPa}$. The corresponding mean CMR above $7.0 \mathrm{hPa}$ is given in Table 3.

lated 55 Dobson units (DU). The SBUV extrapolated amount, based on latitude and months of the campaign, is 34-37 DU, corresponding to a 6 ppmv CMR extrapolation. Which value is correct and what imprecisions do the extrapolations introduce into the integrated ozone column? The 55 DU value in Figure 3 (corresponding to the $10 \mathrm{ppmv}$ isoline) is too high (see figures in McPeters et al. [1997]). However, the 6 ppmv (36 DU) curve may be too low if we consider that deviations from the observed ozone start at 12
$\mathrm{hPa}$ where the ozone and radiosonde readings are still reliable (this is less so above $10 \mathrm{hPa}$ ). These extremes, representing a $\pm 20 \mathrm{DU}$ difference, bracket the uncertainty in a typical extrapolation.

[17] The $1 \sigma$ uncertainty in upper stratospheric ozone partial pressure over the Kaashidhoo campaign that appears in Figure $3 \mathrm{a}$ is typically $\pm 5 \%$ of the mean partial pressure. Figure 4 is a time-series of stratospheric ozone obtained by subtracting integrated tropospheric ozone from total ozone

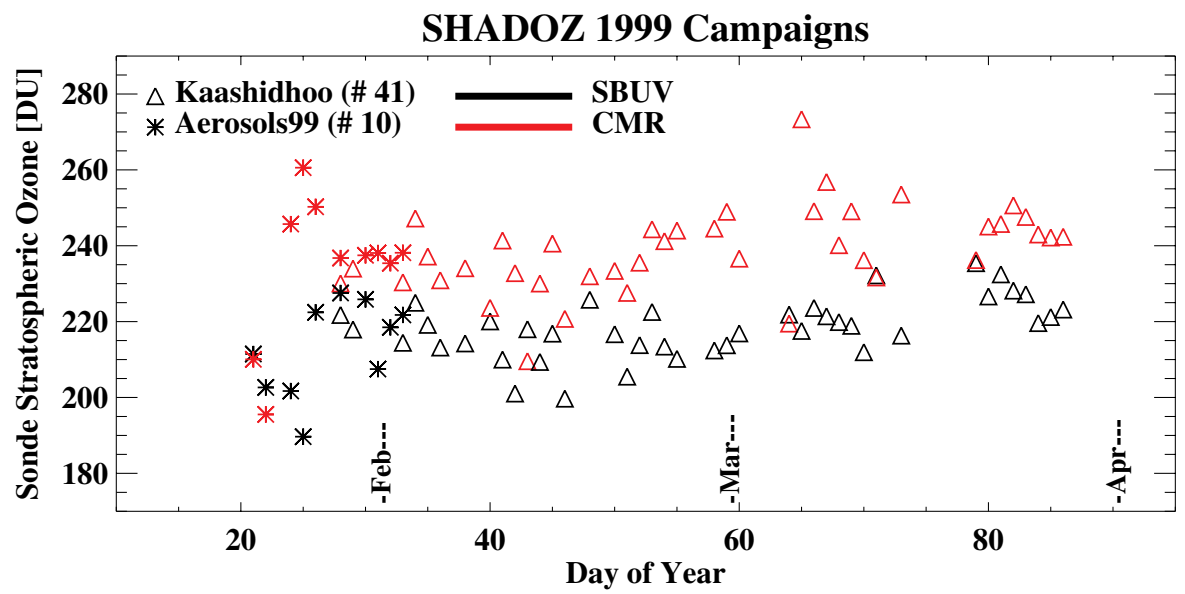

Figure 4. Stratospheric ozone computed from soundings at Kaashidhoo during INDOEX (triangles) and from Aerosols 99 cruise (launches to $\pm 20^{\circ}$ latitude, asterisks). Stratospheric column amount computed by subtracting integrated tropospheric ozone from the sonde total ozone. Campaign data are color-coded in black (SBUV) and red (CMR) to illustrate the two extrapolation techniques. 


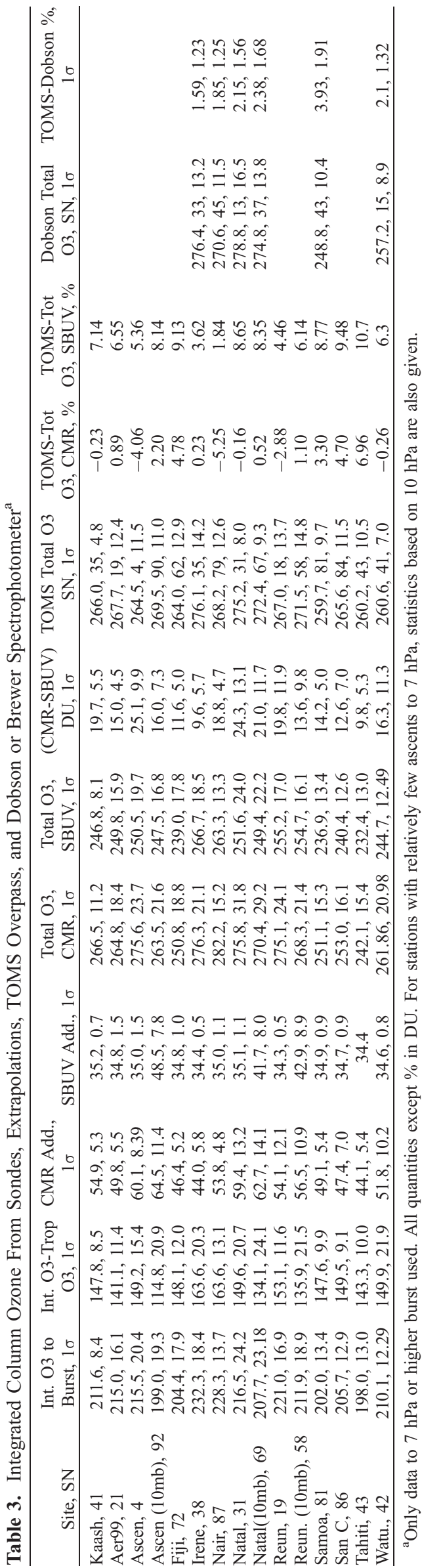

computed with SBUV (black $\triangle$ ) and with CMR (red-brown $\triangle$ ) for the 41 Kaashidhoo soundings represented in Figure 3a. For some soundings, CMR-based stratospheric ozone is less than the SBUV-based value; for three soundings the stratospheric ozone amounts coincide (overlapping $\triangle$ ). This is not surprising, given that each sonde instrument is new and the climatological SBUV value is only an estimate for the Kaashidhoo observing period. The variance $(1 \sigma)$ of stratospheric ozone column is 9.5 DU with SBUV and 11 DU with constant mixing ratio (Table 3); this translates into $4 \%$ and $5 \%$, respectively, in total ozone. Results of daily launches that reached $7.0 \mathrm{hPa}$ on Aerosols99 [Thompson et al., 2000] are similar to those at Kaashidhoo (Figure 3b; * in Figure 4). Thus, $5 \%$ imprecision appears to be a reasonable estimate for total column ozone from a sounding. This imprecision estimate has also been deduced from laboratory and field tests [Barnes et al., 1985; Johnson et al., 2002].

\subsection{Time-Series at SHADOZ Sites}

[18] Statistics for soundings that burst at $7.0 \mathrm{hPa}$ and above for SHADOZ stations are similar to those for the Kaashidhoo and Aerosols99 campaigns, even though the observing period is longer. Table 3 summarizes statistics on CMR and SBUV for all 1998-2000 station soundings. The Pacific stations (Samoa, San Cristóbal, Fiji, Tahiti) have relatively small upper stratospheric ozone, small variance in the stratospheric column, and the $1 \sigma$ standard deviation for ozone above $7 \mathrm{hPa}$ is $11 \%$ (5-6 DU standard deviation, 44-49 DU CMR mean, Table 3). The effect on total ozone uncertainty is only $\sim 3 \%$. Table 3 shows that CMR extrapolations based on $7 \mathrm{hPa}$ range from $44 \mathrm{DU}$ (Irene) to $60 \mathrm{DU}$ (Ascension).

\section{SHADOZ Sonde Accuracy Determined From Independent Ozone Measurements}

[19] At five SHADOZ stations, ground-based instrumentation for total ozone also operates. Dobson total ozone spectrophotometers at four SHADOZ stations (American Samoa, Nairobi, Natal, Irene) were calibrated during 19981999 to $2-3 \%$ accuracy with the world standard Dobson instrument (R. Evans, personal communication, 2000). The Brewer at Watukosek met the international Brewer standard in 1996 and 2000. Comparisons are made between instruments that measure total ozone and sonde total column amounts, using SBUV extrapolation and CMR for soundings that reached $7.0 \mathrm{hPa}$ or $10 \mathrm{hPa}$ (for Ascension, Natal, Réunion). TOMS overpass data, from the instrument on the Earth-Probe satellite, are also compared to sonde ozone column because the satellite is regularly calibrated and comparisons are possible at all sites (Table 3 ). The measurement of TOMS total ozone is considered accurate to $2-3 \%$ [McPeters and Labow, 1996].

\subsection{Comparisons of SHADOZ and Ground-Based Total Ozone With TOMS}

[20] For the Kaashidhoo total ozone values, comparison with TOMS total ozone measured during each day's satellite overpass appears in Figure 5. TOMS total ozone agrees with the sounding total ozone computed with CMR to within $0.3 \%$; total ozone with SBUV is $7 \%$ lower than TOMS (Table 3). TOMS comparisons with total ozone from the 


\section{SHADOZ Site $=$ Kaashidhoo, Maldives Sonde and TOMS Overpass}

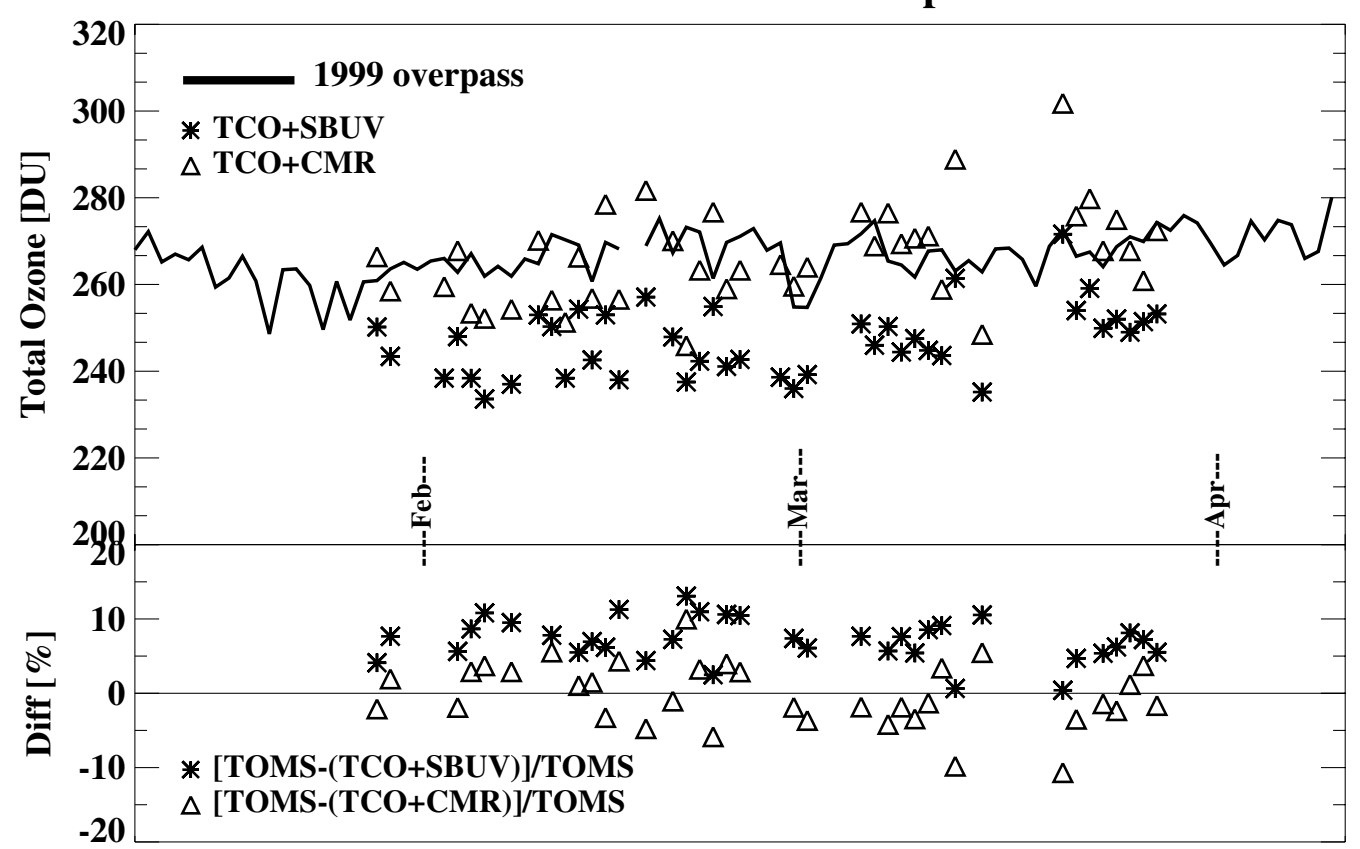

\section{Day of Year}

Figure 5. Comparison of integrated total ozone computed with $\operatorname{CMR}(\triangle)$ and $\operatorname{SBUV}(*)$ for Kaashidhoo launches, compared to TOMS overpass data (solid line), Level 2, version 7 (January-March 1999). Difference relative to TOMS appears in bottom panel.

Aerosols99 cruise (Table 3) are nearly identical to those for Kaashidhoo.

[21] Comparisons of sonde total ozone with the TOMS overpasses for SHADOZ stations appear in Figure 6. Timeseries of total ozone comparisons for the five SHADOZ stations with ground-based measurements are included (dots for Dobson and Brewer data). Total ozone from the sondes, computed with $\operatorname{SBUV}(\triangle)$ extrapolation, are given with TOMS total ozone (solid line). Percentage differences, relative to the total ozone sensors (TOMS, Dobson, Brewer), appear in the lower part of each frame. The summary of Dobson and TOMS means and differences with one another and with the sondes appear in Table 3. The difference between total ozone calculated using CMR instead of SBUV (7th and 8th columns, using $10 \mathrm{hPa}$ statistics for Ascension, Natal and Réunion) ranges from 10 to 21 DU or $\sim 3-8 \%$ of total ozone. If the calibrations of the Dobson and Brewer instruments are accurate to $2-3 \%$, the ground-based instruments give total ozone at Natal, Nairobi and Irene as (270-278) DU $\pm(12-17)$ DU, in good agreement with sonde total ozone and with the TOMS overpass data on average. The Dobson at Samoa (mean = 249 DU) and Brewer average at Watukosek (257 DU) are lower, illustrating the zonal wave-one (section 5).

[22] At Samoa (Figure 6a) sonde total ozone is 9\% lower than TOMS with SBUV (Table 3) and the Dobson total ozone is $4 \%$ lower than TOMS. Section 5 and Appendix A discuss a possible instrument reason for the low sonde total ozone relative to the Dobson. The reason for high TOMS ozone relative to the Dobson and sondes is a known tendency for the TOMS ozone algorithm to overestimate total ozone over regions with tropospheric ozone column $<20$ DU [Wellemeyer et al., 1997]. The climatological ozone profile used in the TOMS algorithm assumes greater tropospheric ozone than is normally found over low-ozone stations in the Pacific. The higher TOMS ozone value at Samoa shows in the TOMS-Dobson-sonde total ozone scatterplot (Figure 7a). The best fit lines are parallel to one another with nearly the same slope. For Nairobi and Irene (Figures $7 \mathrm{~b}$ and $7 \mathrm{c}$ ), the TOMS-sonde and TOMSDobson scatterplots overlap within the highest-density range of values.

[23] Because Table 3 shows that the two stations with best agreement between TOMS and Dobson total ozone are Irene and Nairobi (both $>1 \mathrm{~km}$ in altitude), it is tempting to ascribe larger differences at other stations to tropospheric ozone algorithm effects. However, two tests show that this is not the case. First, if TOMS-sonde differences are due to tropospheric ozone, the differences should correlate with the amount of ozone in the lower troposphere and not with the stratospheric column. Using Samoa to represent a station where there is likely to be a tropospheric algorithm artifact, integration of ozone amounts within the profile shows a correlation of $42 \%$ between the offset amount and the mean troposphere ozone column. However, there is still $27 \%$ correlation between the offset and the stratospheric ozone column. Similar results are obtained at the other SHADOZ stations, with a few of them more highly correlated with the TOMS-sonde offset in the stratosphere than in the troposphere. Apparently, some of the total ozone difference 
(a) SHADOZ Site $=$ Am. Samoa

Sonde, TOMS Overpass, and Dobson Total Ozone Data (@7mb)

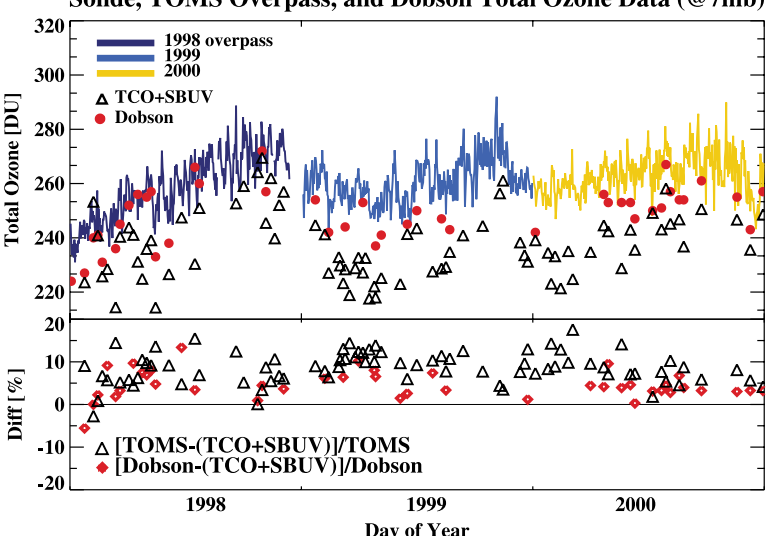

(c) SHADOZ Site $=$ Natal, Brazil

Sonde, TOMS Overpass, and Dobson Total Ozone Data (@10mb)

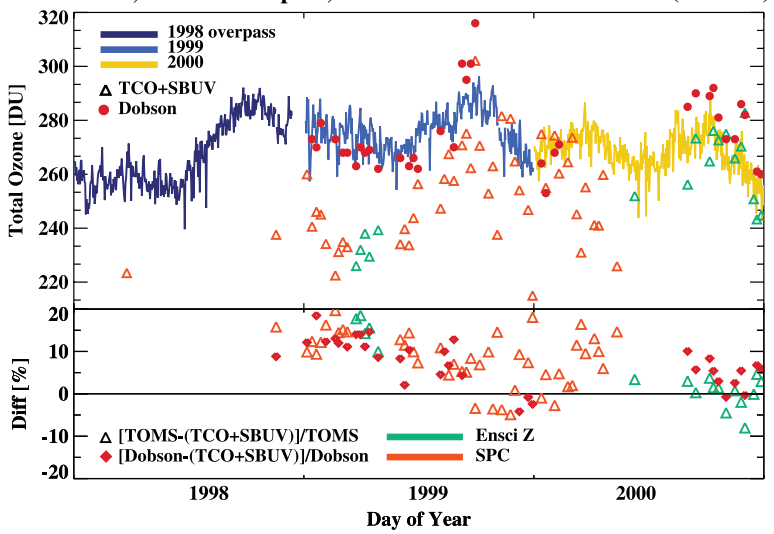

SHADOZ Site= San Cristobal, Galapagos
Sonde, TOMS Overpass Total Ozone Data (e)

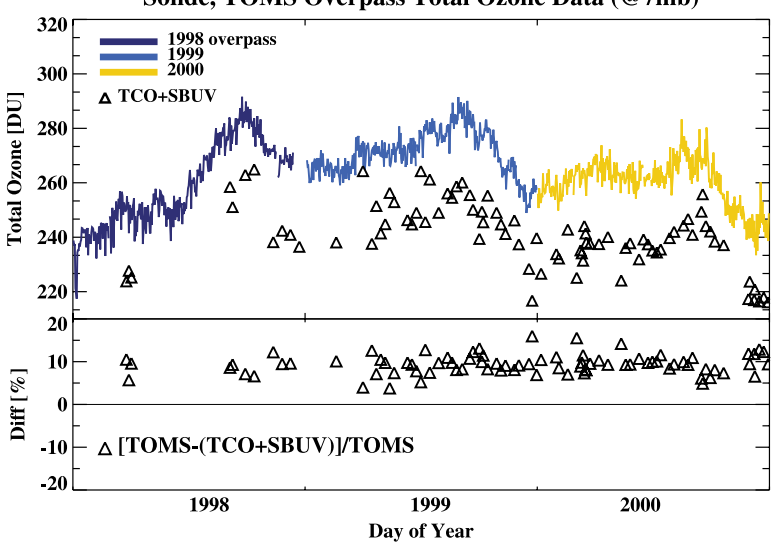

(g) SHADOZ Site= Ascension Is.

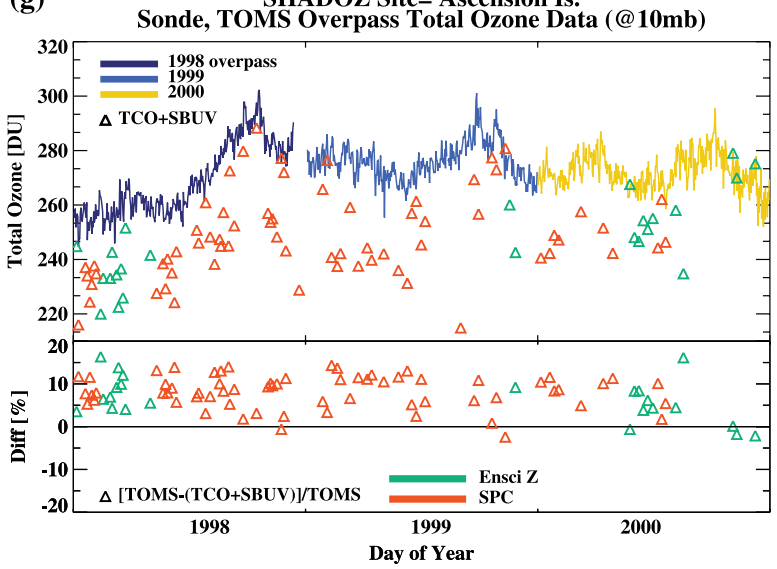

(b) SHADOZ Site= Nairobi, Kenya

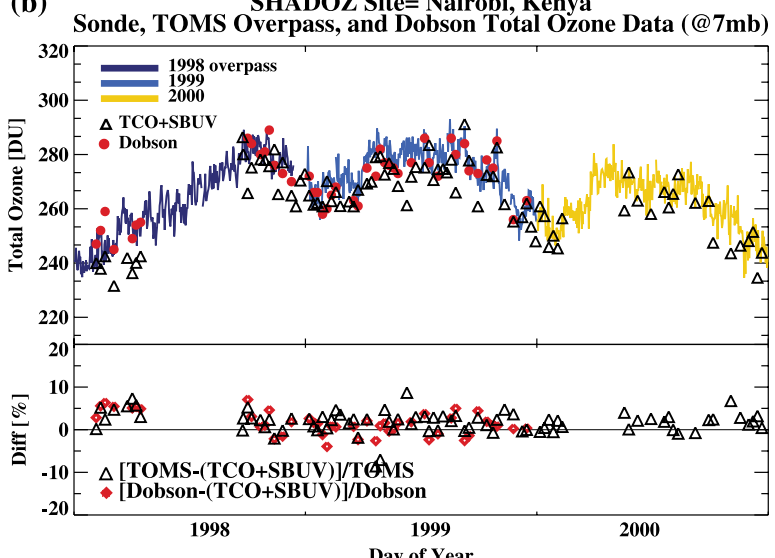

(d) SHADOZ Site= Irene, South Africa

Sonde, TOMS Overpass, and Dobson Total Ozone Data (@7mb)

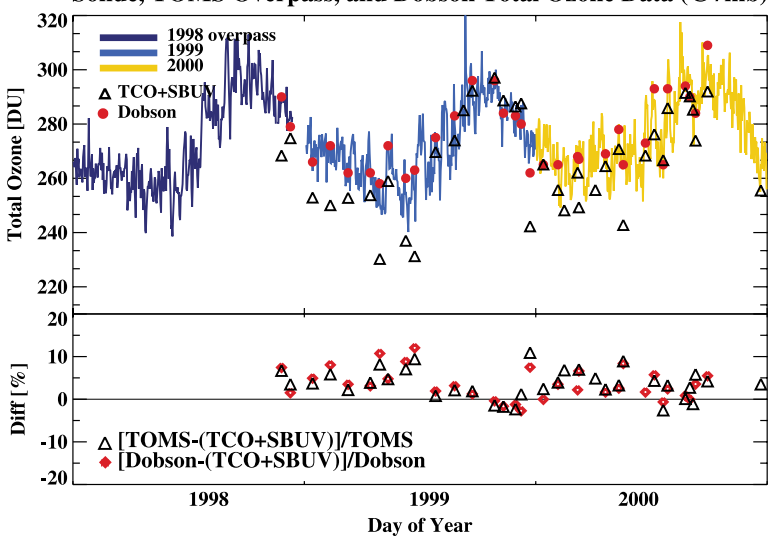

(f) SHADOZ Site $=$ La Reunion Is.

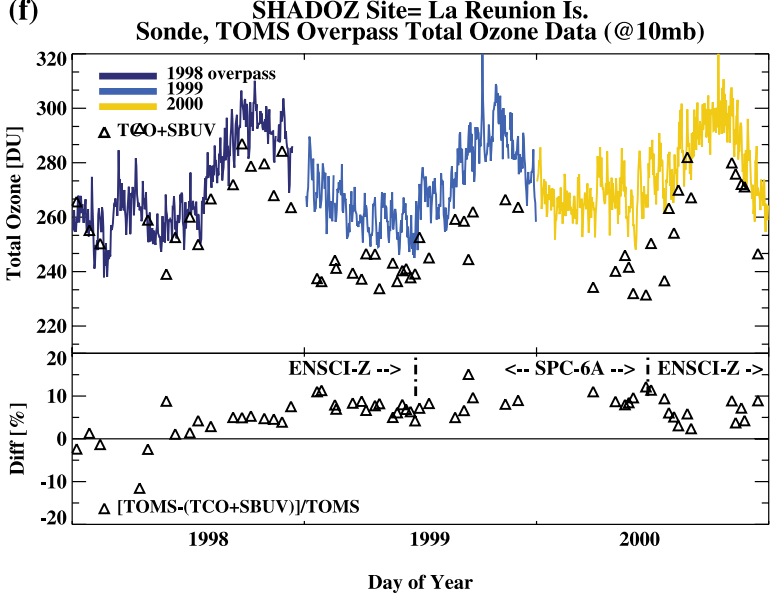

(h) SHADOZ Site= Watukosek-Java

Sonde, TOMS Overpass, and Brewer

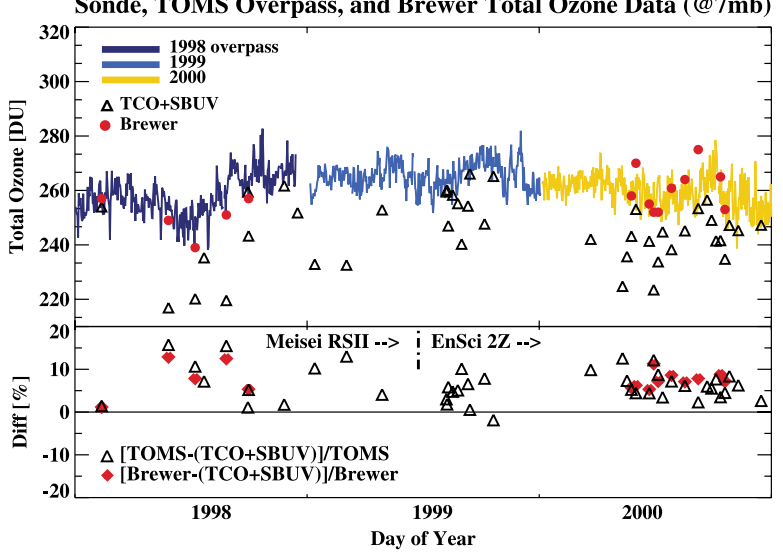



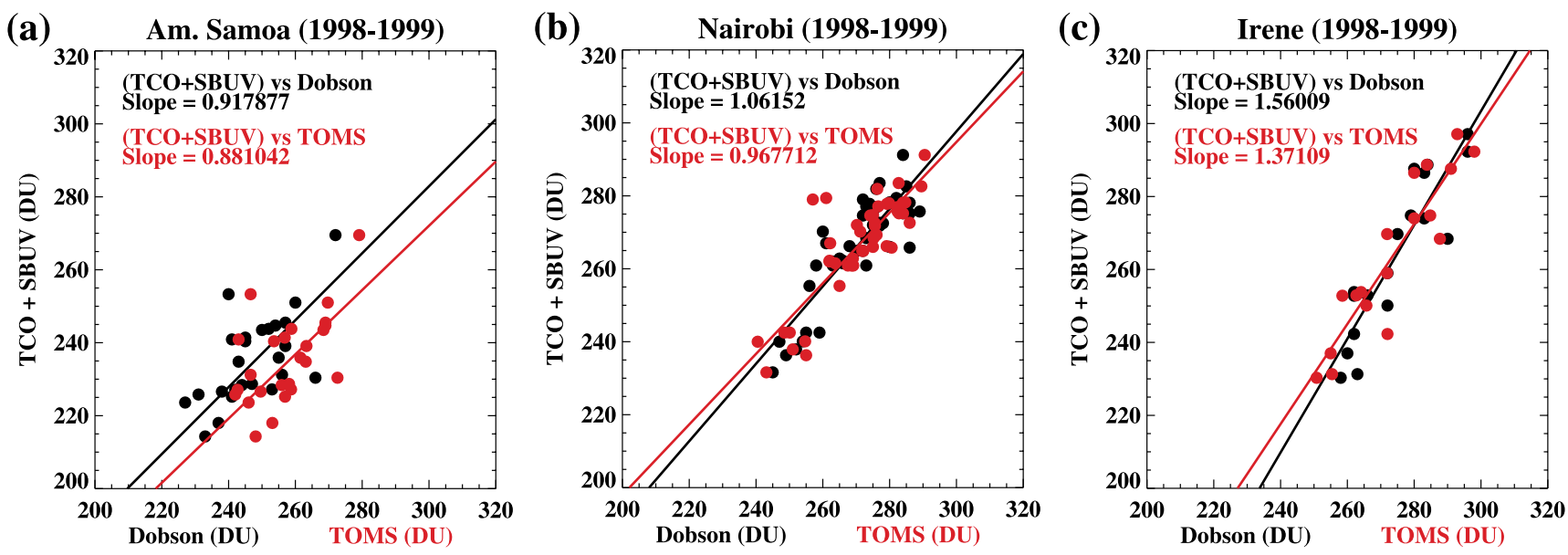

Figure 7. Scatterplots of total ozone sonde launches versus Dobson readings (black) and TOMS overpass (red). (A) American Samoa; (B) Nairobi; (C) Irene.

comes from the stratospheric part of the profile. The second indication that stratospheric ozone contributes to the TOMS-sonde total ozone difference comes from comparison of tropospheric ozone measured by the satellite with tropospheric ozone determined from the sondes.

\subsection{Tropospheric Ozone Satellite-Sonde Comparisons}

[24] Figure 8 compares integrated tropospheric ozone from six sites with the corresponding TOMS-based column tropospheric ozone determined by the modified-residual method [Hudson and Thompson, 1998; Thompson and Hudson, 1999]. For integration using the sonde, the tropopause is defined as the pressure altitude at which the steep gradient from the lower stratosphere crosses $100 \mathrm{ppbv}$ ozone. This chemically defined tropopause does not differ significantly from the tropopause defined by the radiosonde thermal gradient. The chemical tropopause agrees within $\pm 0.7 \mathrm{~km}$ of standard published meteorological analyses. The difference between the satellite and sonde tropospheric ozone averages 6-7 DU, comparable to the precision of the modified-residual technique and less than the corresponding discrepancies between sonde and TOMS total ozone in many cases (Table 3, columns 7 and 9).

\section{Station-to-Station Differences in SHADOZ Column Ozone and Implications for the Equatorial Wave-One}

[25] From sections 3 and 4, we conclude that sonde precision for total ozone is $5 \%$, slightly less than Dobson or TOMS precision. In addition to issues of instrument imprecision, the range of instrument techniques used at SHADOZ stations may result in station-to-station biases and systematic differences between ozone amounts determined from the sondes and from independent measurements. These are evident, for example, when looking at the zonal distribution of total ozone from the SHADOZ sondes. When plotted longitudinally over a short period of time (a month, for example), total ozone from the sondes fail to capture the persistent wave-one feature seen by TOMS. This appears to be a result of station-to-station variations in technique as well as precision limits. Given that assessment of comparative instrument performance is still underway [ $W M O, 1998 \mathrm{~b}](\mathrm{H}$. Smit, personal communication, 2001), we cannot give a definitive evaluation of station biases in terms of instrument or technique used. Instead, we use observations from the large number of soundings within the SHADOZ data set to investigate sonde performance under field conditions. In this section four parameters in the SHADOZ data set are examined.

\subsection{Comparisons of Sonde Ozone With Dobson and TOMS Total Ozone}

[26] Differences between total ozone from the sondes and Dobson, with respect to TOMS, are summarized in Figure 9. Three features are noteworthy. First, the Dobson total ozone leads one to conclude that TOMS total ozone is overestimated up to $4 \%$, depending on location (cf. Table 3). Second, although TOMS reads $\sim 4 \%$ too high over the Samoa Dobson, TOMS is $9 \%$ greater than total ozone from the Samoa sondes (with SBUV). Third, offsets between total ozone and the independent ozone data vary from station to station, although there is some consistency with longitude. The stations over the Pacific are very low in sonde total ozone with respect to TOMS. Two stations (Nairobi, Irene) come closest to TOMS.

[27] That the four Pacific sites (Fiji, Samoa, Tahiti and San Cristóbal) are similar to one another is not surprising. Ozone climatology shows that these stations are generally similar in the stratosphere and troposphere and in seasonal behavior (Tables 3 and 4) [see Oltmans et al., 2001]. Furthermore, all four Pacific sites use uniform procedure,

Figure 6. (opposite) A comparison of integrated total ozone from sondes (TCO) plus SBUV (triangle), TOMS satellite (Level 2, version 7) overpasses, and total ozone from colocated Dobson instruments (red dots) at (A) Samoa; (B) Nairobi; (C) Natal; (D) Irene. TOMS overpass and sonde ozone only at (E) San Cristóbal; (F) Réunion; (G) Ascension; (H) TOMS overpass, sonde and Brewer total ozone at Watukosek. Data to $7 \mathrm{hPa}$ used for all stations except Natal, Réunion, and Ascension (10 hPa bursts). \% deviation relative to TOMS and ground-based instrument in lower panels. 
(a)

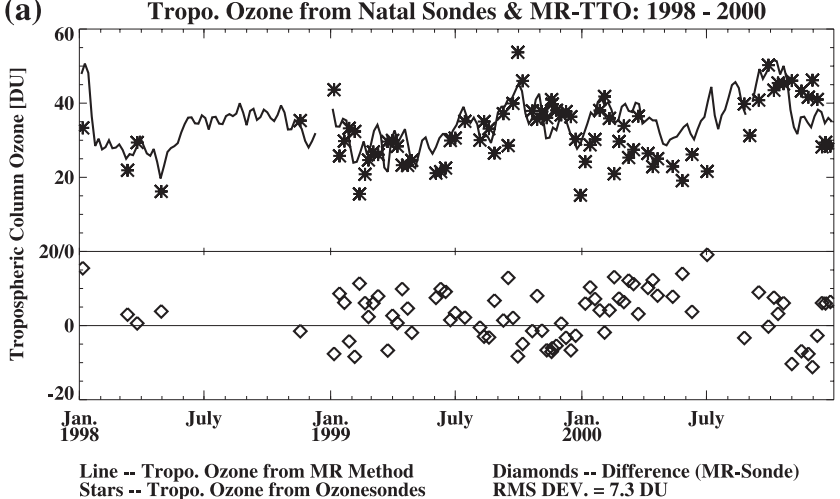

(c) Tropo. Ozone from Ascension Sondes \& MR-TTO: 1998 - 2000

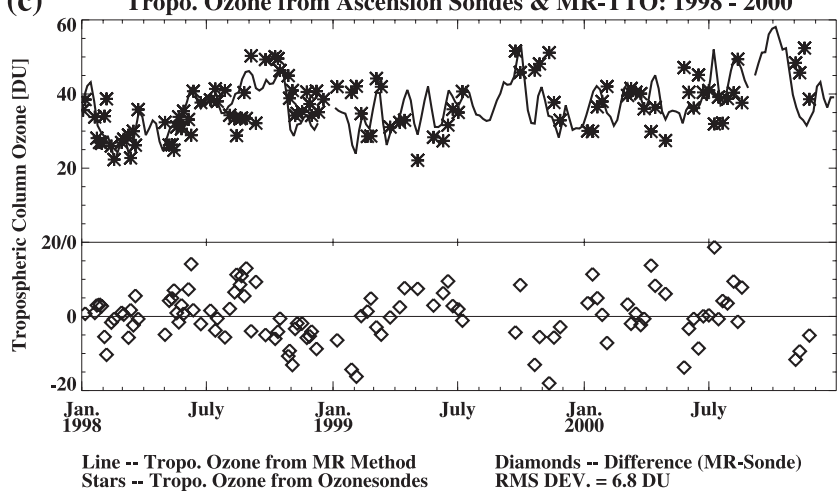

(e) Tropo. Ozone from San Cristobal Sondes \& MR-TTO: 1998 - 2000

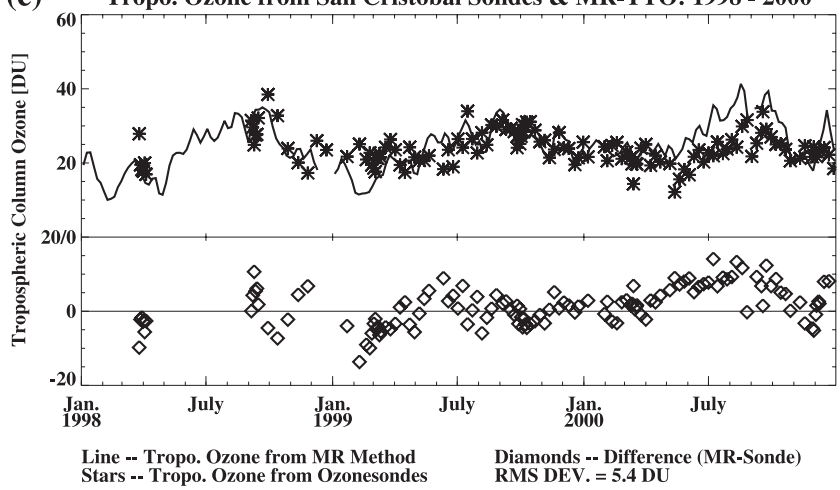

(b) Tropo. Ozone from Nairobi Sondes \& MR-TTO: 1998 - 2000

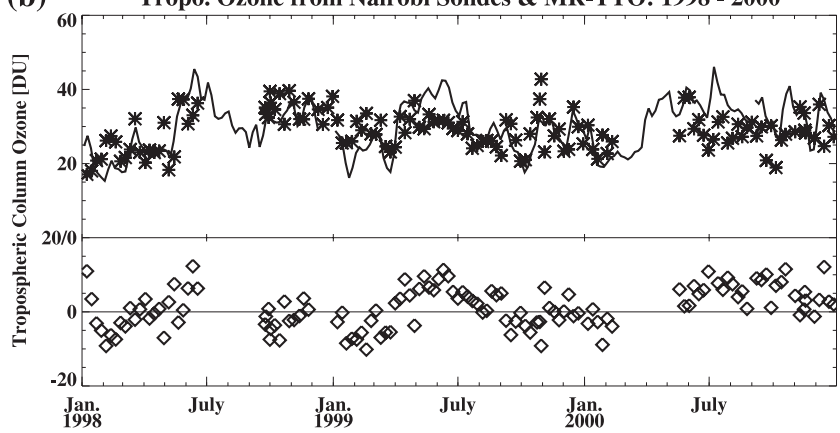

$\begin{array}{ll}\text { Line -- Tropo. Ozone from MR Method } & \text { Diamonds -- Difference (MR-Sonde) } \\ \text { Stars -- Tropo. Ozone from Ozonesondes } & \text { RMS DEV. }=5.6 \text { DU }\end{array}$

(d) Tropo. Ozone from Am. Samoa Sondes \& MR-TTO: 1998 - 2000

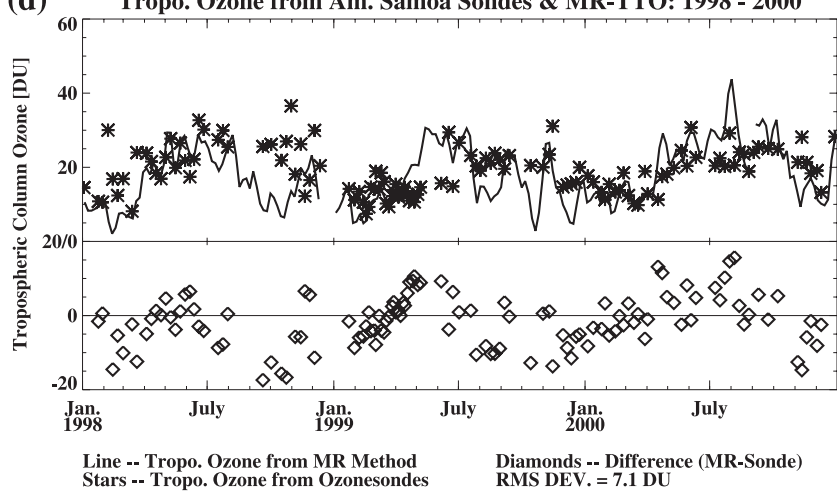

(f) Tropo. Ozone from Watukosek-Java Sondes \& MR-TTO: 1998 - 2000

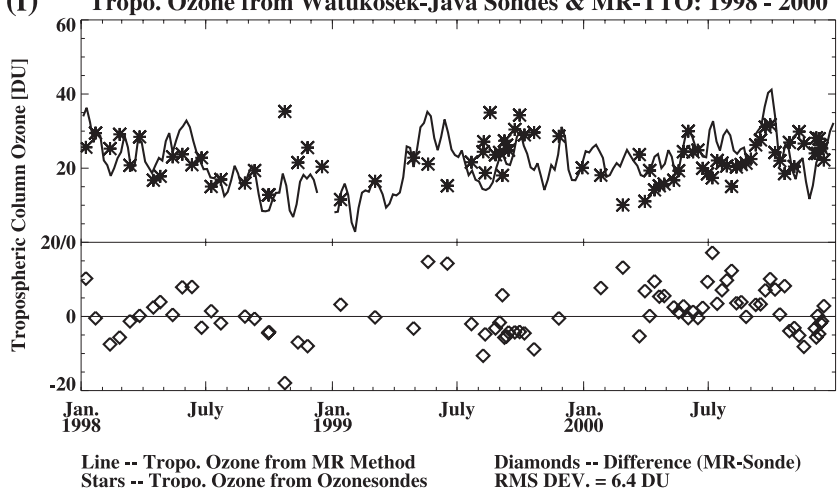

Figure 8. Integrated tropospheric ozone for six SHADOZ sites $(*)$ with 9-day averaged tropospheric ozone for the corresponding location derived from TOMS by the modified-residual method [Thompson and Hudson, 1999]. Nine-day running averages of TOMS data are used to minimize equatorial data gaps, scan angle artifacts and aerosol effects. The modified-residual method is restricted to tropical air masses, which are defined as being within the zone of the wave-one feature in total ozone-usually at $\pm 20^{\circ}$ from the equator. (A) Natal, (B) Nairobi, (C) Ascension, (D) Samoa, (E) San Cristóbal, (F) Watukosek. Lower panel displays percent differences from satellite reading.

hardware, measurement and processing techniques (Appendix A, Table A1). The Aerosols99 and Kaashidhoo campaigns differed from the Pacific stations only in the hardware used. Based on preliminary results from JOSIE 2000 and other tests [Johnson et al., 2002], there is a suggestion that the type of ozonesonde instrument used in the Pacific stations gives systematically lower total ozone than the instrument used during the Aerosols99 cruise and Kaashidhoo sampling. Offsets in the latter data sets are 23\% less than at the Pacific stations where the same sonde preparation and data processing were used (CMDL method, Appendix A). The same instrument bias might also explain different offsets between sondes and TOMS at Irene and Nairobi where the same preparation is used with different instruments. However, other SHADOZ data are ambiguous concerning instrument type ozone biases (Appendix A).

[28] A definitive evaluation of instrument accuracy and station-to-station instrumental effects requires examination of sonde profiles and is beyond the scope of this paper. However, we attempt to learn more about potential sources 


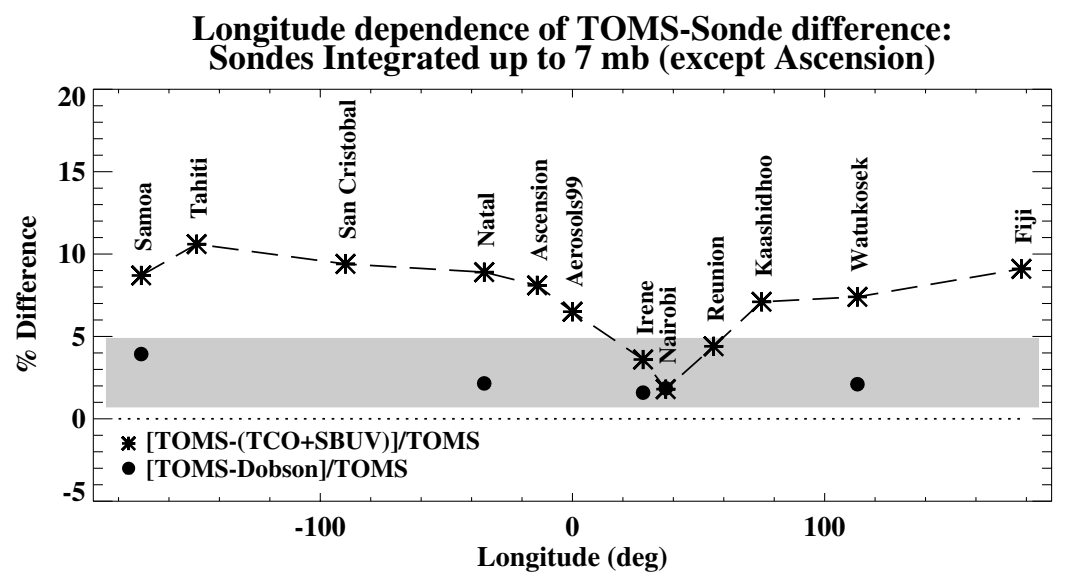

Figure 9. Summary of averaged differences between total ozone from TOMS and SHADOZ sondes and between TOMS and Dobsons where measurements were taken. Data to $7 \mathrm{hPa}$ (or to $10 \mathrm{hPa}$, Table 3) with SBUV extrapolation are used for sonde total ozone calculation. Measurements from early 1999 field campaigns (Aerosols99 data from 20N-20S over the Atlantic and Kaashidhoo Observatory during INDOEX) are included. Shaded region is "best estimated value" based on Dobson data and EP/TOMS calibration.

of variability in SHADOZ data by considering three aspects of the stratospheric portion of the profiles.

\subsection{Stratospheric Ozone Variability}

[29] On average, stratospheric ozone is uniform among the tropical SHADOZ stations (Table 4). Figure 10 shows the measured stratospheric ozone column to $7 \mathrm{hPa}$ obtained by subtracting integrated tropospheric ozone from the sonde-measured total (with SBUV, Table 3, 3rd column). Measured mean stratospheric ozone falls within 11 DU (143 DU [Tahiti] to 153 DU [Réunion]) at all but two stations: Irene and Nairobi. Higher stratospheric ozone at Irene is explained by a higher frequency of midlatitude air (signified by a tropopause height $2-3 \mathrm{~km}$ lower than for the other stations, not shown). Reasons for higher stratospheric column ozone at Nairobi are less clear. A strong response to the QBO, a 20 DU increase in stratospheric ozone for nearly one-third of the SHADOZ record, was detected at Nairobi but was not unique to this station (J. A. Logan et al., The quasi-biennial oscillation in tropical ozone as revealed by ozonesonde data, submitted to Journal of Geophysical Research, 2002). Nairobi shows a tendency toward relatively higher ozone in the uppermost part of the measured profile, above the ozone maximum (not shown). This is depicted in one of the highest CMR extrapolations (shown relative to SBUV, Figure 11) compared to all the stations.

Table 4. Mean Ozone Column Amounts Averaged From SHADOZ Soundings Taken During 1998-2000

\begin{tabular}{|c|c|c|c|c|c|c|c|c|}
\hline \multirow[b]{2}{*}{ Station } & \multirow{2}{*}{\multicolumn{2}{|c|}{ Sample No. }} & \multicolumn{2}{|c|}{ TOTAL, DU } & \multicolumn{2}{|c|}{ Stratosphere, DU } & \multicolumn{2}{|c|}{ Troposphere, DU } \\
\hline & & & Mean & $1 \sigma$ & Mean & $1 \sigma$ & Mean & $1 \sigma$ \\
\hline Samoa & \multicolumn{2}{|c|}{111} & 236.1 & 12.8 & 216.8 & 9.5 & 19.0 & 6.2 \\
\hline Tahiti & \multicolumn{2}{|c|}{68} & 237.8 & 15.2 & 216.3 & 12.0 & 21.5 & 6.3 \\
\hline San Cris. & \multicolumn{2}{|c|}{125} & 240.2 & 13.9 & 216.3 & 11.8 & 25.2 & 4.4 \\
\hline Ascension & \multicolumn{2}{|c|}{109} & 249.6 & 15.1 & 213.1 & 10.1 & 37.9 & 7.1 \\
\hline Natal & \multicolumn{2}{|c|}{82} & 249.5 & 21.2 & 217.5 & 16.3 & 32.0 & 8.4 \\
\hline Nairobi & \multicolumn{2}{|c|}{130} & 260.2 & 14.0 & 231.2 & 11.6 & 29.6 & 5.3 \\
\hline Reunion & \multicolumn{2}{|c|}{78} & 253.2 & 15.9 & 219.5 & 10.7 & 37.7 & 8.2 \\
\hline Kaash(99) & \multicolumn{2}{|c|}{48} & 246.0 & 8.6 & 217.7 & 8.2 & 28.3 & 5.1 \\
\hline Fiji & \multicolumn{2}{|c|}{116} & 240.5 & 16.9 & 218.8 & 11.4 & 21.5 & 7.6 \\
\hline \multirow[t]{2}{*}{ Watukosek } & \multicolumn{2}{|c|}{68} & 240.2 & 20.9 & 217.0 & 19.6 & 29.1 & 5.5 \\
\hline & \multicolumn{2}{|c|}{ Sample No. } & \multicolumn{2}{|c|}{ TOTAL Mean } & \multicolumn{2}{|c|}{ Stratosphere Mean } & \multicolumn{2}{|c|}{ Troposphere Mean } \\
\hline Station & MAM & SON & MAM & SON & MAM & SON & MAM & SON \\
\hline Samoa & 33 & 19 & 229.2 & 252.2 & 212.4 & 228.5 & 18.9 & 23.0 \\
\hline Tahiti & 24 & 17 & 225.8 & 256.7 & 208.3 & 230.0 & 17.6 & 26.7 \\
\hline Fiji & 35 & 24 & 232.6 & 259.7 & 215.0 & 231.3 & 17.6 & 28.4 \\
\hline San Cris. & 38 & 41 & 236.6 & 246.1 & 216.1 & 218.8 & 20.5 & 28.4 \\
\hline Ascension & 29 & 30 & 242.4 & 262.7 & 209.7 & 219.5 & 35.3 & 44.6 \\
\hline Nairobi & 29 & 38 & 256.9 & 265.8 & 228.4 & 234.9 & 28.5 & 32.3 \\
\hline Reunion & 18 & 20 & 243.3 & 269.6 & 212.9 & 228.6 & 34.0 & 45.2 \\
\hline Watukosek & 4 & 24 & 232.6 & 241.8 & 211.0 & 217.0 & 27.2 & 26.9 \\
\hline Natal & 20 & 22 & 242.4 & 268.8 & 209.7 & 227.4 & 35.3 & 41.3 \\
\hline
\end{tabular}

${ }^{a}$ The number of samples is given. The lower part of the table is based on soundings taken on March-April-May (MAM) and September-October-November (SON). 
Longitude coverage of stratospheric column amount up to $7 \mathrm{mb}$

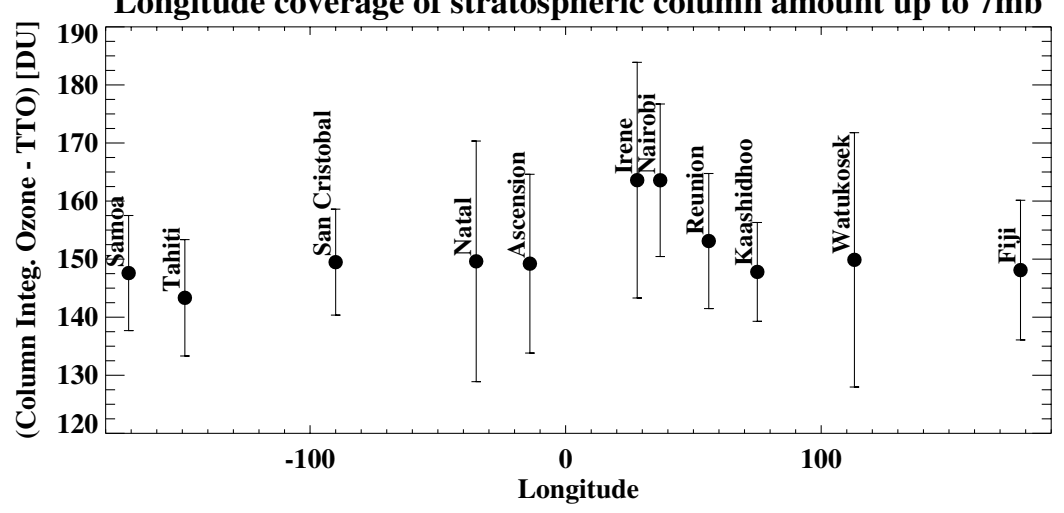

Figure 10. Zonal view of stratospheric column ozone determined by subtracting integrated tropospheric ozone from total ozone computed with SBUV extrapolation. Bars indicate $1 \sigma$ standard deviation. Irene stratospheric column is relatively higher because mid-latitude stratospheric conditions frequently prevail.

Figure 12 shows that Nairobi has no bias relative to other stations in the lower stratosphere/upper troposphere ("UT/ LS," represented by the $15-20 \mathrm{~km}$ column integral). In Figure 12, as expected, Irene has the highest mean value (23 DU). All other stations average between 10 and 15 DU so the UT/LS ozone column is uniform over the tropical stations. The implications for the wave-one pattern in equatorial ozone are discussed in section 5.4. Other variations among stations that are displayed in Figure 11 suggest relatively high upper stratosphere ozone at Natal and Ascension (high CMR relative to SBUV) and relatively low upper stratospheric ozone at Fiji, Tahiti, San Cristóbal and Samoa. This contrasts with similar column amounts for all of these stations in the UT/LS. Note, however, that the $15-20 \mathrm{~km}$ integrated ozone is a small fraction of the stratospheric column.

\subsection{Evaluation of the SBUV Add-On for the SHADOZ Region}

[30] With the statistics in Table 3 (and Figures 9-12) based on hundreds of soundings, there is enough data to evaluate the SBUV climatology, assuming that discrepancies between sonde total ozone and the total ozone instruments are due to extrapolation errors. If the Dobson and/or
Brewer data are taken as a group, Figure 9, with shaded values depicting the most likely correct range of total ozone, suggests that TOMS total ozone is $2-4 \%$ too high. Depending on location, sonde total ozone computed with SBUV is 4-11\% lower than TOMS (except for Nairobi). To bring the sonde totals into agreement with the ground-based instruments at Natal, Samoa, Irene and Watukosek, would require $2-7 \%$ more ozone $(5-17.5$ DU, assuming a 250 DU mean total ozone; Table 4). Because of the calibration of SBUV instrument, a 17.5 DU figure for extrapolation from $7 \mathrm{hPa}$ is likely to be too high. Adding 5-7 DU to the SBUV add-on would be reasonable and would bring sonde total ozone closer to the range suggested by the ground-based instruments. Note that if a low-ozone instrument bias affects the Pacific stations (Fiji, Tahiti, Samoa, San Cristóbal), as Johnson et al. [2002] believe, the sonde-Dobson ozone offset at Samoa would be reduced.

\subsection{Zonal Distribution of Ozone and the Equatorial Wave-One}

[31] A number of studies [Shiotani and Hasebe, 1994; Kim et al., 1996; Ziemke et al., 1996; Hudson and Thompson, 1998] have attempted to isolate the location of the equatorial wave-one pattern in total ozone, i.e. is it in the

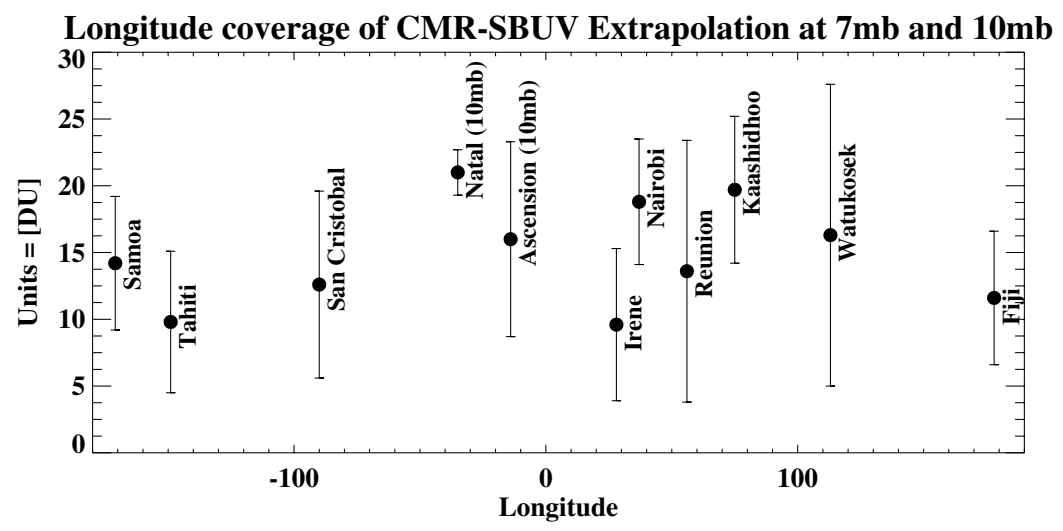

Figure 11. Zonal view of the difference between average CMR extrapolations and SBUV for SHADOZ stations and Kaashidhoo data with $1 \sigma$ standard deviation. Except for Natal and Ascension (to $10 \mathrm{hPa}$ ), data to $7 \mathrm{hPa}$ are used in integrating ozone. 


\section{Longitude coverage of 15-20km Integrated Column Amount}

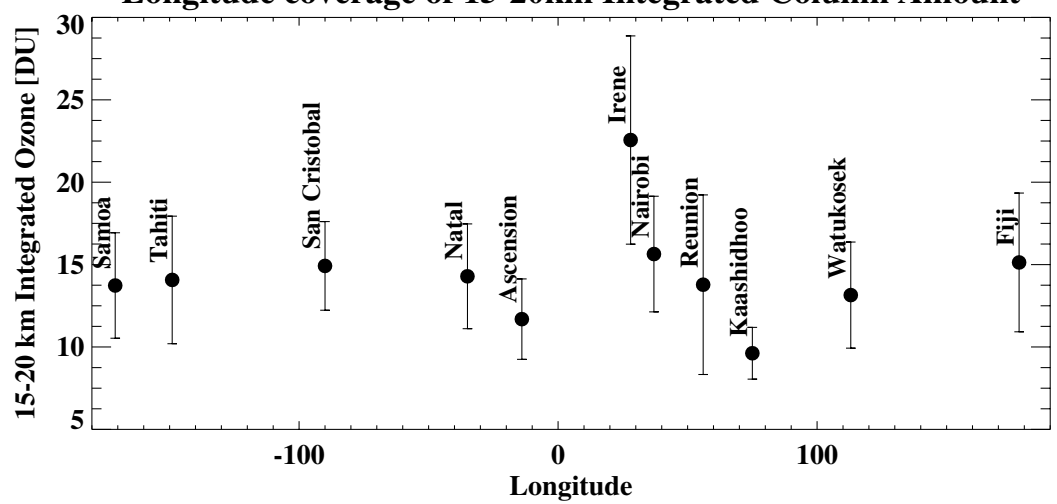

Figure 12. Zonal view of integrated column ozone (DU) between 15 and $20 \mathrm{~km}$, with $1 \sigma$ standard deviation.

troposphere, the stratosphere or both? With the assumption that the excess Atlantic ozone is located in the lower stratosphere, satellites, usually at poorest precision at these altitudes, are of limited use. Consequently, the longitudinal coverage of SHADOZ was designed to observe the zonal structure of tropical ozone profiles for the first time. Figures 10-12 do not support a picture of a stratospheric wave-one. The measured total stratospheric column (Figure 10) is zonally invariant if the Nairobi and Irene (less tropical in character) sondes are omitted. The $15-20 \mathrm{~km}$ ozone column is the same at all tropical stations, within uncertainties (Figure 12), i.e. no lower stratospheric wave-one appears.

[32] How do the uncertainties and possible biases of sondes affect interpretation of the equatorial wave-one pattern? Given the precision limits on each ozonesonde (5\%) and natural variability (up to $10 \%$ of total ozone annually; Figure 6) the column integrals do not show a

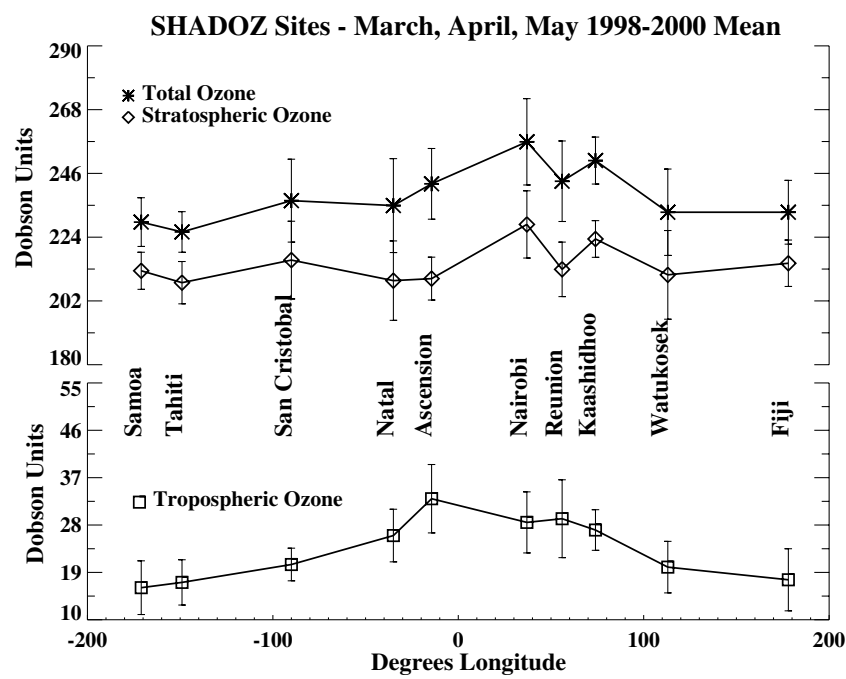

Figure 13. Seasonally averaged March-April-May total (asterisk), stratospheric (diamond) and tropospheric ozone column from 1998 to 2000 SHADOZ data. Integration for total ozone based on SBUV add-ons and stratospheric ozone is obtained by subtracting the integrated tropospheric ozone column from total ozone. Mean and $1 \sigma$ standard deviation are shown. total ozone wave-one with the SHADOZ data as a whole. This is clear when total ozone $( \pm 1 \sigma)$ from Table 4 is plotted as a function of longitude (not shown). Seasonally averaged column amounts can be used to look at the wave-one because on this time-scale total ozone data variability approaches the 5\% sonde uncertainty. Figures 13 and 14 present the seasonal means (to $\pm 1 \sigma$ ) for total, stratospheric and tropospheric column ozone, respectively, for MarchApril-May (MAM) and September-October-November (SON). The wave-one in total ozone is more clearly observed, with Natal, Ascension, Nairobi and Réunion spanning the regions of maximum ozone. During MAM and SON, lower total ozone occurs at the four Pacific stations and Watukosek. The relatively lower total ozone at Fiji, Samoa and Tahiti is not as pronounced during SON, when these sites are subject to ozone pollution transported from Africa, SE Asia and/or Australia [Oltmans et al., 2001].

[33] Table 5 shows integrated total, stratospheric and tropospheric ozone averaged over the sets of four stations, Natal-Ascension-Nairobi-Réunion (representative of the ozone maximum region) and Watukosek-Fiji-Tahiti-

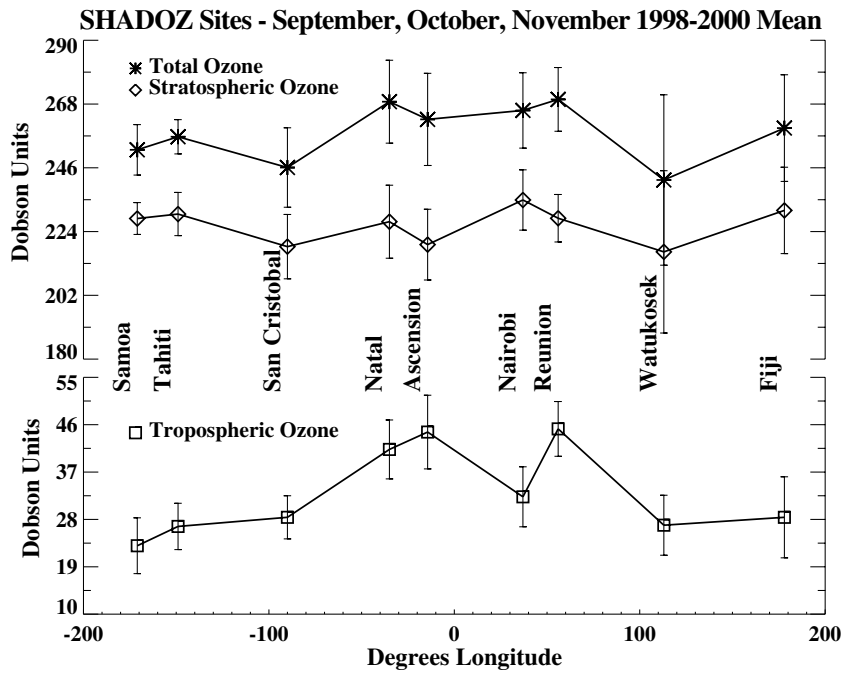

Figure 14. Same as Figure 13 except that SeptemberOctober-November averages are shown. 
Table 5. Wave-One Amplitude Based On Average 1998-2000 Column-Integrated Sonde Amounts From SHADOZ (Table 4)

\begin{tabular}{|c|c|c|c|c|}
\hline Season & Nat-Asc-Nai-Reu, DU & Wat-Fij-Sam-Tah-San Cris, DU & Difference, DU & Mean $\sigma$, DU \\
\hline \multicolumn{5}{|c|}{ March-April-May } \\
\hline Total Ozone & 246.3 & 231.4 & 14.9 & 5.5 \\
\hline Strat. Ozone & 215.3 & 212.5 & 2.8 & 5.5 \\
\hline Trop. Ozone & 33.3 & 20.4 & 12.9 & 3.6 \\
\hline \multicolumn{5}{|c|}{ September-October-November } \\
\hline Total Ozone & 266.7 & 251.3 & 15.4 & 3.1 \\
\hline Strat. Ozone & 227.4 & 227.6 & -0.2 & 6.4 \\
\hline Trop. Ozone & 40.9 & 26.7 & 14.1 & 5 \\
\hline
\end{tabular}

${ }^{\mathrm{a}}$ Stations between $40 \mathrm{~W}$ and $65 \mathrm{E}$ are used to represent the ozone maximum region; stations between $110 \mathrm{E}$ and $90 \mathrm{~W}$ represent the ozone minimum.

Samoa-San Cristóbal (representing the ozone minimum). An estimate of wave magnitude is obtained by subtracting the two means. Total ozone shows a wave-one amplitude equal to $15( \pm 5)$ DU in both MAM and SON. Stratospheric ozone shows a small (not statistically significant) wave or none at all. In both MAM and SON there is a tropospheric wave, 13-14 $( \pm 5)$ DU. The tropospheric wave-one in MAM occurs during an annual minimum in southern hemisphere biomass burning [Thompson et al., 2003], evidently for dynamical reasons. A smaller dynamically driven wave, enhanced by (mostly) pyrogenic ozone concentrated between eastern South America and Africa, is presumably responsible for the SON wave-one [Thompson et al., 1996b; Fishman et al., 1996; Moxim and Levy, 2000]. The vertical structure of the zonal wave-one in the tropospheric ozone as captured by the SHADOZ sondes is described by Thompson et al. [2003].

[34] Besides capturing the persistent wave, Figures 13 and 14 depict seasonal variations in total, stratospheric and tropospheric ozone. Total ozone is $10-25$ DU greater in SON than in MAM (cf. Table 4, lower). At stations with little pollution ozone (Nairobi, for example, under normal conditions), total and stratospheric ozone show similar seasonal differences. The impact of seasonal transport of midtropospheric ozone from biomass burning has been documented at Natal [Logan and Kirchhoff, 1986; Kirchhoff et al., 1991, 1996], Ascension [Fishman et al., 1992; Olson et al., 1996; Thompson et al., 1996b], Watukosek [Komala et al., 1996; Fujiwara et al., 1999, 2000] and Réunion [Baldy et al., 1996; Taupin et al., 1999]. More remote from source regions are the Pacific sites, where persistent high-ozone layers introduced by biomass burning have been described by Newell et al. [1999] and Oltmans et al. [2001]. Elevated tropospheric ozone at Watukosek was also detected in sondes following the 1997 El-Niño-related fires [Fujiwara et al., 1999]. However, Thompson et al. [2001] determined that over the maritime continent in general, approximately half the 1997 tropospheric ozone increase was dynamical, not photochemical in origin. The apparent lack of tropospheric ozone seasonality in the 1998-2000 Watukosek data may be an artifact of the noisier instrument used for about half the record. Using only data from the ECC period, August-November tropospheric ozone at Watukosek averaged $24 \pm 8.3$ DU compared to $19 \pm 7.5$ DU in April-July 2000. Table 5 (and Figures 13 and 14) show small seasonal differences at Nairobi, where pollution influences are not consistently strong. For example, in early September 2000, Nairobi soundings averaged $\sim 30$ DU tropospheric ozone whereas tropospheric ozone from soundings at Lusaka, Zambia, in the midst of urban and rural burning, averaged 45 DU [Thompson et al., 2002].

\section{Summary}

[35] The SHADOZ project has been described, including background and goals, archive status and issues of sonde technique that may affect interpretation of the data. Noting that each sonde launched is a different instrument, statistics from three years of ozone data from 10 sites and 2 campaigns are used to estimate uncertainties in the SHADOZ data set and to assess the impact of variations in sonde technique and hardware among the stations. Further insight into possible instrument biases and sonde accuracy comes from comparisons of column ozone amounts with ground-based and satellite ozone data. The key results are:

1. The imprecision in total ozone column measured by an ozonesonde is $\sim 5 \%$.

2. Good agreement (within $2-4 \%$ ) is found between total ozone from TOMS and colocated ground-based instruments at Natal, Nairobi, Irene, Watukosek and American Samoa. For total ozone from the sondes and TOMS, the agreement is poorer $(2-11 \%$, using sonde extrapolation with SBUV).

3. The best sonde-Dobson-TOMS agreement in total ozone is at the two sites with highest terrain (Nairobi and Irene). Although this could be interpreted as evidence that TOMS insensitivity in the lowest troposphere is the main cause for sonde-satellite discrepancies, several tests show that this is not the case. Discrepancies evidently arise also from the stratospheric part of the ozone profile.

4. Agreement with TOMS tropospheric ozone and integrated tropospheric ozone from the sondes is very good. Typical mean discrepancy is 6-7 DU-the precision limit of the TOMS tropospheric ozone-and is comparable at all stations within $15^{\circ}$ of the equator.

5. Station-to-station differences in the total ozone TOMS-sonde-Dobson agreement are sometimes consistent with biases in sonde technique or in TOMS. In other cases, sonde samples do not follow the behavior expected for the instrument:

- The sensor instrument model used at the four Pacific stations may be a contributing factor to total ozone at Samoa from the sondes being lower than the Dobson ozone total.

- Similarly, the TOMS algorithm assumes several percent too much ozone over the Pacific. When the latter two factors are taken into account, total ozone from TOMS- 
Dobson-sondes are in agreement with one another within $2 \%$.

- Two different types of ECC instruments were used at Ascension, San Cristóbal, Natal and Réunion during the 1998-2000 period. The Réunion and San Cristóbal samples sorted by instrument type resemble results of laboratory tests, but there was no apparent effect of a hardware change at Ascension and Natal.

- The column amount difference between total ozone with the two types of instruments that have been used at Watukosek is consistent with recent chamber tests with ozonesonde instruments but not within parts of the profile.

6. On average, the stratospheric ozone column is the same at all but two sites (within 10 DU). The exceptions are at Irene (which frequently receives midlatitude air) and at Nairobi.

7. Due to station-to-station biases and natural ozone variability, the wave-one pattern in total ozone cannot always be observed with the sondes. However, seasonal means show a statistically significant wave-one pattern in total ozone and a tropospheric wave of the same magnitude $(\sim 15 \mathrm{DU})$ and a longitudinally uniform stratosphere (no wave).

[36] The uniformity of equatorial stratospheric ozone validates the assumption made in several residual-type tropospheric ozone retrievals that the tropical stratosphere is zonally constant. A follow-up paper will discuss the structure of the tropospheric wave [Thompson et al., 2003].

\section{Appendix A: Techniques and Characteristics of Individual SHADOZ Sites}

[37] Although all SHADOZ sites use electrochemical concentration cell (ECC) technology [Komhyr, 1967], various stations prepare their sondes and process the raw data differently. There are two reasons for this. First, sonde technology is continuously evolving [Barnes et al., 1985; Beekmann et al., 1994; Komhyr et al., 1995]. Manufacturer recommendations for sonde preparation and processing as well as evaluations of instrument performance by users dictate changes in method from time to time. Second, because all stations were operational at the initiation of SHADOZ (one with data since 1978), it was impractical to specify a uniform procedure. To aid the reader and SHADOZ data user, we give a brief description of how the ECC measurement leads to an ozone value (section A.1). This is followed by a summary of techniques used at the SHADOZ sites (section A.2), including comparisons of data collected at the SHADOZ sites that switched instrumentation during the 1998-2000 period.

\section{A1. Electrochemical Concentration Cell (ECC) Ozonesonde}

[38] The main principle of an ECC sensor is simple. A potential difference is set up between two cells of different strength of KI (potassium iodide) solution [Komhyr, 1967]. The amount of ozone present, as partial pressure, is given as follows:

$$
\begin{aligned}
\mathrm{P}_{\text {ozone }}= & 4.307 \times 10(-4) \times\left(\mathrm{I}-\mathrm{I}_{\mathrm{bg}}\right) \times \mathrm{T}(\text { pump }) \times \mathrm{t}(\text { flow }) \\
& \times \mathrm{C}_{\text {eff }} \times \mathrm{C}_{\text {ref }}
\end{aligned}
$$

The current, I, that develops due to electrochemical reactions from introducing ozone into the sensor is given relative to a "no-ozone" background value, $\mathrm{I}_{\mathrm{b}}$, measured in the laboratory prior to the balloon flight. The first term on the rhs is a units conversion that incorporates the gas constant and the Faraday constant to give the ozone partial pressure, which is reported in each profile data record. The other terms are the flow rate, measured in the laboratory prior to launch, and two correction terms. The $\mathrm{C}_{\text {eff }}$ factor accounts for a slowdown in the efficiency of the ozonesonde pump as higher altitudes and lower temperatures are encountered. This is most critical above $25 \mathrm{~km}$. The second correction is to normalize the entire column amount to an independently determined total ozone column, either from satellite or from a colocated total ozone instrument (usually a Dobson or Brewer). The latter step is omitted from the sonde profiles in SHADOZ data files.

[39] Uncertainties are the flow rate ( $1-2 \%$ at the ground), extrapolation to the top of the atmosphere, which is based on climatology (the balloon only reaches $4-7 \mathrm{hPa}$; see section 3.1), the pump efficiency correction $\left(\mathrm{C}_{\text {eff }}\right)$ and the response time of the solution. The pressure, determined by the radiosonde, becomes noticeably more uncertain with altitude. Temperature uncertainties are $0.5 \mathrm{~K}$. The humidity determination is deemed reliable to several percent up to $\sim 12 \mathrm{~km}$. The pump efficiency correction is the greatest source of uncertainty in the profile as a whole $(10-15 \%$ above $25 \mathrm{~km}$ ) [Komhyr, 1986; DeBacker et al., 1998]. An additional uncertainty comes from the strength of the KI solution used and whether or not the solution is buffered [Boyd et al., 1998; WMO, 1998a, 1998b; Johnson et al., 2002].

[40] Differences among ozonesonde technique are not easy to resolve. A test-chamber sponsored by ForschungZentrum (FZ)-Jülich and the WMO has been used for several comparisons of sonde performance in a controlled environment that simulates the atmosphere $[W M O, 1998 \mathrm{~b}$; $\langle$ www.fz-juelich.de/icg/icg2/forschung/Josie $\rangle$ ]. Of the groups participating in SHADOZ, only the NOAA/CMDL ECC system used at the four SHADOZ sites in the Pacific was tested in the 1996 comparison (JOSIE = Jülich Ozonesonde Intercomparison Experiment). During JOSIE-1996 $[W M O, 1998 \mathrm{~b}]$ the NOAA sondes appeared to read higher than the standard ozone "tropical stratospheric" profile and not significantly different in the "tropical troposphere". After that time, NOAA sonde preparation and processing procedures were modified and Samoa, Tahiti and Fiji data from 1995 to 1998 were reprocessed [Johnson et al., 2002; Oltmans et al., 2001].

[41] Chamber tests performed at FZ-Jülich in September 2000 (JOSIE-2000) were conducted by 4 SHADOZ groups and included all methods currently used in the network. The results and impact on SHADOZ data are currently being analyzed. A limitation of the chamber approach is that model profiles are highly idealized compared to the layering typically found in the tropics [Newell et al., 1999]. In addition to chamber tests, field comparisons need to be conducted, i.e. with several instruments flown simultaneously on a single balloon [Hilsenrath et al., 1986].

\section{A2. Summary of Ozonesonde Procedures at SHADOZ Stations}

[42] The procedures used to collect SHADOZ data at the end of 2000 appear in Table A1. 


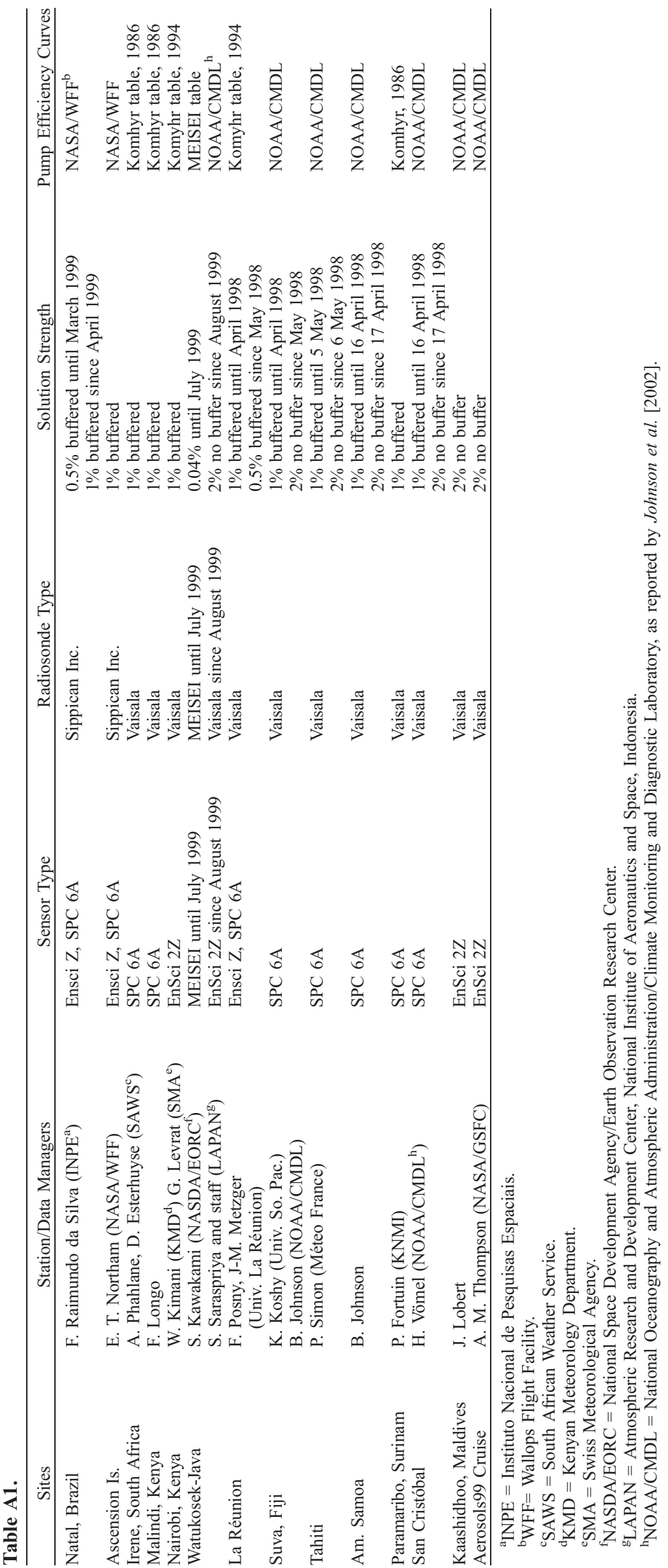


[43] All of the SHADOZ sites are subject to reprocessing and a website caveat reminds users that the data are subject to change. Note that each station (Table 1) processes the raw data for SHADOZ in the way that has been customary for the site, so that data are not strictly comparable from one station to the next. Data users are urged to contact the station Coinvestigator (addresses and email at the SHADOZ website) for details on current operating characteristics and reprocessing.

[44] Four SHADOZ stations changed sonde instrument during the 1998-2000 period. Data at Réunion Island and a small set of San Cristóbal samples reveal a systematic bias between ozone determined with the different procedures. At San Cristóbal, 11 ENSCI instruments were launched within the otherwise all-SPC series. Ozone from the SPC sondes averaged 2 DU lower than TOMS total ozone, whereas total ozone from ENSCI data averaged 18 DU $(\sim 7 \%)$ higher. For Réunion, inspection of Figure $6 \mathrm{f}$ (lower panel) reveals sondederived ozone from the SPC-6A instrument lower than from ENSCI data. Measured column amounts to $10 \mathrm{hPa}$ are:

Reunion ENSCI: $217.7 \pm 17.4$ DU (43 samples)

Reunion SPC: $196.8 \pm 13.1$ DU (16 samples).

These differences agree with laboratory tests described by Johnson et al. [2002] and with a possible lower-ozone bias by SPC when SHADOZ Pacific data are compared to the Aerosols99 and Kaashidhoo soundings (section 5.1). At Natal and Ascension (Figures $6 \mathrm{c}$ and $6 \mathrm{~g}$ ), however, instrument switches did not lead to noticeable differences. Measured to $10 \mathrm{hPa}$ :

\section{Ascension ENSCI: $195.5 \pm 20.0$ DU (25 samples) \\ Natal ENSCI: $206.6 \pm 18.6$ DU(18 samples) \\ Ascension SPC: $200.2 \pm 18.9 \mathrm{DU}(67$ samples $)$ \\ Natal SPC: $208.0 \pm 24.8$ DU(51 samples).}

(Note, that for Natal, the change in instrument type change was accompanied by a recommended sensor solution change, so some of the 1998-1999 data have been reprocessed to be consistent with other Natal data. Total ozone did not change significantly on average. The modified data are available at the SHADOZ website.) At Watukosek, the MEISEI RSIIKC79D instrument was flown from the start of ozonesonde launches in 1993 until July 1999, when an ENSCI ground station was installed. Figure A1 shows a comparison of mean ozone (partial pressure) and temperature profiles from the 1993-1999 record at Watukosek, labeled "MEISEI-All" and based on 129 sondes. A subset of 28 MEISEI profiles were taken in the first part of the SHADOZ period, from January 1998 to July 1999. Mean temperature and ozone mixing ratio appear in Figure A1. The mean profiles from ENSCI sensor data from July 1999 to December 2000 (57 soundings) are also shown in Figure A1. Integrated column ozone for the mean MEISEI ozone profile is $13 \%$ lower than for the corresponding ENSCI column amount. Nearly all of this difference is due to stratospheric discrepancies because tropospheric column amounts average 23 DU for both sets of profiles. For the lower stratosphere, JOSIE-1996 [WMO, 1998b] showed that MEISEI readings can be lower than ENSCI due to a slower response time of the MEISEI instrument. This does not appear to explain the lower

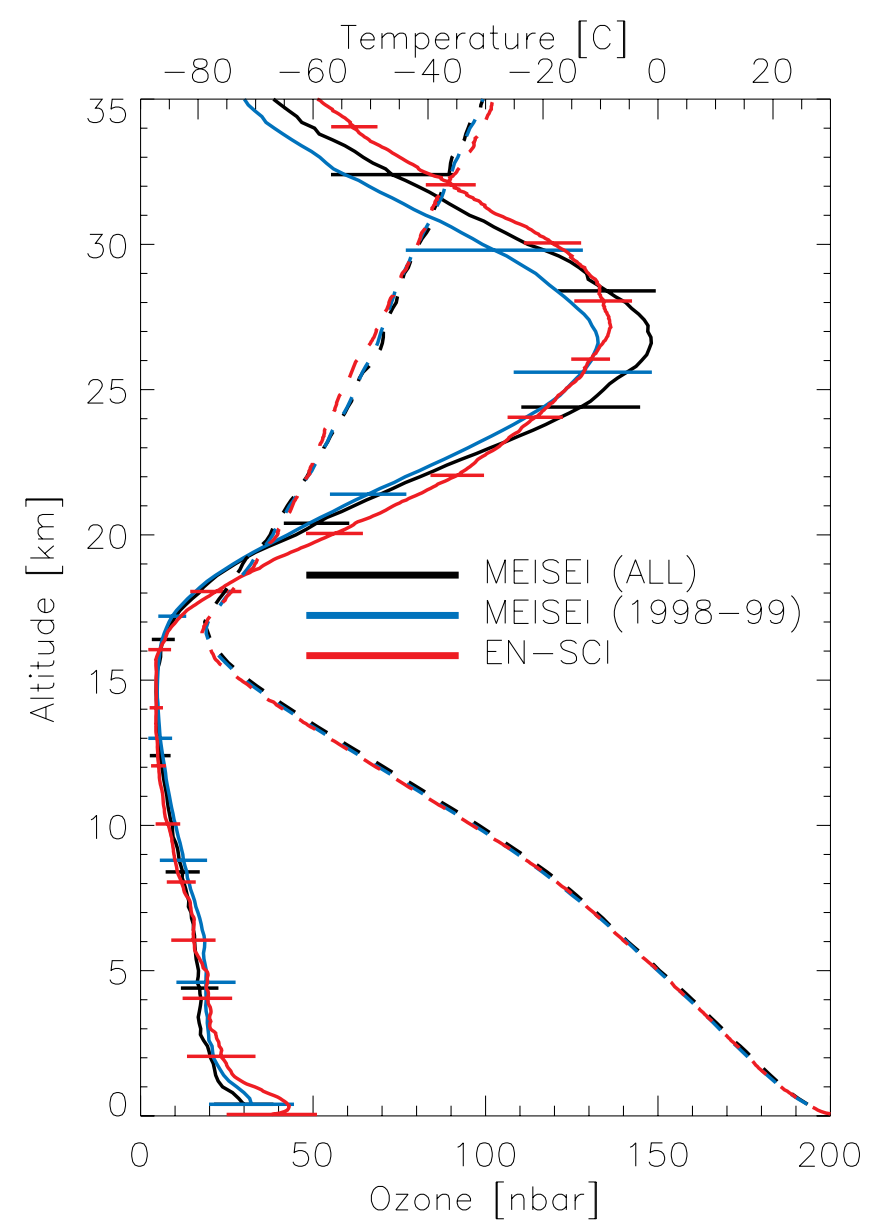

Figure A1. A comparison of ozone and temperature profiles taken at Watukosek with MEISEI and EN-SCI type sondes. "All" refers to 1993-July 1999 data; "MEISEI, 1998-1999” were taken as part of SHADOZ.

MEISEI values in the upper stratosphere in Figure A1. JOSIE-2000 may offer further insight into MEISEI-ENSCI differences.

[45] Acknowledgments. SHADOZ is supported by NASA's Atmospheric Chemistry Modeling and Analysis Program (ACMAP) and the TOMS project. Individual SHADOZ sites are supported by in-country agencies and universities, including NOAA, NASDA (National Space Development Agency of Japan), LAPAN (Lembaga Pener Rangan Bangan Dan Antariksa Nasional, the National Institute of Aeronautics and Space Agency of Indonesia), INPE (Instituto dos Nacional de Pesquisas Espaciais, the National Space Agency of Brazil), the South African Weather Service, the Swiss Meteorological Agency, the Kenyan Meteorological Department, the University of the South Pacific (Suva, Fiji) and the University of Réunion Island (France). SHADOZ has benefited greatly from JOSIE-2000 and WMO workshops on ozone instrumentation (sponsored by M. Proffitt and H. Smit) and we appreciate the opportunity to participate.

\section{References}

Baldy, S., G. Ancellet, M. Bessafi, A. Badr, and D. L. S. Luk, Field observations of the vertical distribution of tropospheric ozone at the island of Reunion (southern tropics), J. Geophys. Res., 101, 23,835-23,849, 1996.

Barnes, R. A., A. R. Bandy, and A. L. Torres, Electrochemical concentration cell ozone sonde accuracy and precision, J. Geophys. Res., 90, 7881-7887, 1985.

Beekmann, M., G. Ancellet, G. Megie, H. G. J. Smit, and D. Kley, Intercomparison campaign of vertical ozone profiles including electrochemical sondes of ECC and Brewer-Mast Type-A ground-based uv-differential absorption lidar, J. Atmos. Chem., 19, 259-288, 1994. 
Bhartia, P. K., R. D. McPeters, C. L. Mateer, L. E. Flynn, and C. Wellemeyer, Algorithm for the estimation of vertical ozone profiles from the backscattered ultraviolet technique, J. Geophys. Res., 101, 18,79318,806, 1996

Boyd, I. S., G. E. Bodeker, B. J. Connor, D. P. J. Swart, and E. J. Brinksma An assessment of ECC ozonesondes operated using $1 \%$ and $0.5 \% \mathrm{KI}$ cathode solutions at Lauder, New Zealand, Geophys. Res. Lett., 25, 2409-2412, 1998

Burrows, J. P., et al., The global ozone monitoring experiment (GOME) Mission concept and first scientific results, J. Atmos. Sci., 56, 151-175, 1999

Chance, K., W. A. Traub, D. G. Johnson, K. W. Jucks, P. Ciarpallini, R. A Stachnik, R. J. Salawitch, and H. A. Michelsen, Simultaneous measurements of stratospheric $\mathrm{HO}_{\mathrm{x}}, \mathrm{NO}_{\mathrm{x}}$, and $\mathrm{Cl}_{\mathrm{x}}$ : Comparison with a photochemical model, J. Geophys. Res., 101, 9031-9043, 1996.

DeBacker, H., D. Demuer, and D. De Sadelaer, Comparison of ozone profiles obtained with Brewer-Mast and Z-ECC sensors during simultaneous ascents, J. Geophys. Res., 103, 19,641-19,648, 1998.

Diab, R. D., et al., Vertical ozone distribution over southern Africa and adjacent oceans during SAFARI-92, J. Geophys. Res., 101, 23,80923,821, 1996

Fishman, J., and V. G. Brackett, The climatological distribution of tropospheric ozone derived from satellite measurements using version 7 Total Ozone Mapping Spectrometer and Stratospheric Aerosol and Gas Experiment data set, J. Geophys. Res., 102, 19,275-19,278, 1997.

Fishman, J., V. Brackett, and K. Fakhruzzaman, Distribution of tropospheric ozone in the tropics from satellite and ozonesonde measurements, J. Atmos. Terr. Phys., 54, 589-597, 1992.

Fishman, J., V. G. Brackett, E. V. Browell, and W. B. Grant, Tropospheric ozone derived from TOMS/SBUV measurements during TRACE-A J. Geophys. Res., 101, 24,069-24,082, 1996

Fujiwara, M., K. Kita, S. Kawakami, T. Ogawa, N. Komala, S. Saraspriya, and A. Suripto, Tropospheric ozone enhancements during the Indonesian forest fire events in 1994 and 1997 as revealed by ground-based observations, Geophys. Res. Lett., 26, 2417-2420, 1999

Fujiwara, M., K. Kita, T. Ogawa, S. Kawakami, T. Sano, N. Komala, S. Saraspriya, and A. Suripto, Seasonal variation of tropospheric ozone in Indonesia revealed by 5-year ground based observations, J. Geophys. Res., 105, 1879-1888, 2000.

Hasebe, F., et al., Initial results from SOWER/Pacific 1998-2000 campaigns, Proceedings of the 2nd SPARC General Assembly, CD-ROM, 2000.

Hilsenrath, E., et al., Results from the Balloon Ozone Intercomparison Campaign (BOIC), J. Geophys. Res., 91, 13,137-13,152, 1986.

Hudson, R. D., and A. M. Thompson, Tropical Tropospheric Ozone (TTO) maps from TOMS by a modified-residual method, J. Geophys. Res., 103 22,129-22,145, 1998.

Johnson, B. J., S. J. Oltmans, H. Vömel, T. Deshler, C. Kroger, and H. G. J. Smit, ECC ozonesonde pump efficiency measurements and sensitivity tests of buffered and unbuffered sensor solutions, J. Geophys. Res., 107, doi:10.1029/2001JD000557, in press, 2002

Kim, J.-H., R. D. Hudson, and A. M. Thompson, A new method of deriving time-averaged tropospheric column ozone over the tropics using tota ozone mapping spectrometer (TOMS) radiances: Intercomparison and analysis using TRACE-A data, J. Geophys. Res., 101, 24,317-24,330, 1996.

Kirchhoff, V. W. J. H., E. V. Browell, and G. L. Gregory, Ozone measurements in the troposphere of an Amazonian rainforest environment J. Geophys. Res. 93, 15,850-15,860, 1988.

Kirchhoff, V. W. J. H., R. A. Barnes, and A. L. Torres, Ozone climatology at Natal, Brazil, from in-situ ozonesonde data, J. Geophys. Res., 96 , 10,899-10,909, 1991

Kirchhoff, V. W. J. H., J. R. Alves, F. R. da Silva, and J. Fishman, Observations of ozone concentrations in the Brazilian cerrado during the TRACEA field expedition, J. Geophys. Res., 101, 24,029-24,042, 1996.

Kobayashi, J., and Y. Toyama, On various methods of measuring the vertical distribution of atmospheric ozone (III) carbon-iodine type chemica ozonesonde, Pap. Meteorol. Geophys., 17, 113-126, 1966

Komala, N., S. Saraspriya, K. Kita, and T. Ogawa, Tropospheric ozone behavior observed in Indonesia, Atmos. Environ., 30, 1851-1856, 1996. Komhyr, W. D., Nonreactive gas sampling pump, Rev. Sci. Instrum., 38 , 981-983, 1967

Komhyr, W. D., Operations handbook-Ozone measurements to $40 \mathrm{~km}$ altitude with model 4A-ECC-ozone sondes, NOAA Tech. Memo. ERLARL-149, 1986.

Komhyr, W. D., R. A. Barnes, G. B. Brothers, J. A. Lathrop, and D. P. Opperman, Electrochemical concentration cell ozonesonde performance during STOIC, J. Geophys. Res., 100, 9231-9244, 1995.

Lelieveld, J., et al., The Indian Ocean Experiment: Widespread air pollution from South and Southeast Asia, Science, 291, 1031-1036, 2001.

Logan, J. A., Trends in the vertical distribution of ozone: An analysis of ozone sonde data, J. Geophys. Res., 99, 25,553-25,585, 1994.
Logan, J. A., An analysis of ozonesonde data for the troposphere: Recommendations for testing 3-D models and development of a gridded climatology for tropospheric ozone, J. Geophys. Res., 104, 16,115-16,149, 1999a.

Logan, J. A., An analysis of ozonesonde data for the lower stratosphere, $J$. Geophys. Res., 104, 16,151-16,170, 1999b.

Logan, J. A., and V. W. J. H. Kirchhoff, Seasonal-variations of tropospheric ozone at Natal, Brazil, J. Geophys. Res., 91, 7875-7881, 1986.

McPeters, R. D., and G. J. Labow, An assessment of the accuracy of 14.5 years of Nimbus 7 TOMS Version 7 ozone data by comparison with the Dobson network, Geophys. Res. Lett., 23, 3695-3698, 1996.

McPeters, R. D., G. J. Labow, and B. J. Johnson, A satellite-derived ozone climatology for balloonsonde estimation of total column ozone, J. Geophys. Res., 102, 8875-8885, 1997.

Moxim, W. J., and H. Levy, A model analysis of the tropical South Atlantic Ocean tropospheric ozone maximum: The interaction of transport and chemistry, J. Geophys. Res., 107, 17,393-17,415, 2000

Newell, R. E., V. Thouret, J. Y. N. Cho, P. Stoller, A. Marenco, and H. G. Smit, Ubiquity of quasi-horizontal layers in the troposphere, Nature, 398, 316-319, 1999.

Nganga, D., A. Minga, B. Cros, C. Bouka Biona, J. Fishman, and W. B. Grant, The vertical distribution of ozone measured at Brazzaville, Congo, during TRACE-A, J. Geophys. Res., 101, 24,095-24,103, 1996.

Olson, J. R., J. Fishman, V. W. J. H. Kirchhoff, D. Nganga, and B. Cros, An analysis of the distribution of ozone over the southern Atlantic region, J. Geophys. Res., 101, 24,083-24,094, 1996.

Oltmans, S. J., et al., Ozone in the Pacific tropical troposphere from ozonesonde observations, J. Geophys. Res., 106(D23), 32,503-32,525, 2001.

Randriambelo, T., J.-L. Baray, and S. Baldy, Effect of biomass burning, convective venting, and transport on tropospheric ozone over the Indian Ocean: Reunion Island field observations, J. Geophys. Res., 105, $11,813-11,832,2000$

Shiotani, M., Annual quasi-biennial and El Nino-Southern Oscillation (ENSO) time-scale variations in Equatorial total ozone, J. Geophys. Res., 97, 7625-7634, 1992

Shiotani, M., and F. Hasebe, Stratospheric ozone variations in the equatorial region as seen in Stratospheric Aerosol and Gas Experiment data, J. Geophys. Res., 99, 14,575-14,584, 1994.

Smit, H., D. Kley, S. McKeen, A. Volz, and S. Gilge, The latitudinal and vertical distribution of tropospheric ozone over the Atlantic Ocean in the southern and northern hemispheres, in Ozone in the Atmosphere, edited by R. D. Bojkov and P. Fabian, pp. 419-422, 1989

Taupin, F. G., M. Bessafi, S. Baldy, and P. J. Bremaud, Tropospheric ozone above the southwestern Indian Ocean is strongly linked to dynamical conditions prevailing in the tropics, J. Geophys. Res., 104, 8057-8066, 1999.

Thompson, A. M., and R. D. Hudson, Tropical tropospheric ozone (TTO) Maps from Nimbus 7 and Earth-Probe TOMS by the modified-residual method: Evaluation with sondes, ENSO signals and trends from Atlantic regional time series, J. Geophys. Res., 104, 26,961-26,975, 1999

Thompson, A. M., et al., Ozone over southern Africa during SAFARI-92/ TRACE A, J. Geophys. Res., 101, 23,793-23,807, 1996a.

Thompson, A. M., K. E. Pickering, D. P. McNamara, M. R. Schoeberl, R. D. Hudson, J. H. Kim, E. V. Browell, V. W. J. H. Kirchhoff, and D. Nganga, Where did tropospheric ozone over southern Africa and the tropical Atlantic come from in October 1992? Insights from TOMS, GTE/TRACE-A and SAFARI-92, J. Geophys. Res., 101, 24,251$24,278,1996 \mathrm{~b}$

Thompson, A. M., B. G. Doddridge, J. C. Witte, R. D. Hudson, W. T. Luke, J. E. Johnson, B. J. Johnson, S. J. Oltmans, and R. Weller, A tropical Atlantic ozone paradox: Shipboard and satellite views of a tropospheric ozone maximum and wave-one in January-February 1999, Geophys. Res. Lett., 27, 3317-3320, 2000

Thompson, A. M., J. C. Witte, R. D. Hudson, H. Guo, J. R. Herman, and M. Fujiwara, Tropical tropospheric ozone and biomass burning, Science, 291, 2128-2132, 2001.

Thompson, A. M., J. C. Witte, M. T. Freiman, N. A. Phahlane, and G. J. R. Coetzee, Lusaka, Zambia, during SAFARI-2000: Convergence of local and imported ozone pollution, Geophys. Res. Lett., 29(20), 1976 , doi:10.1029/2002GL015399, 2002.

Thompson, A. M., et al., The 1998-2000 SHADOZ (Southern Hemisphere Additional Ozonesondes) tropical ozone climatology, 2, Tropospheric variability and the zonal wave-one, J. Geophys. Res., 108, doi:10.1029/ 2002JD002241, in press, 2003

Wellemeyer, C. G., S. L. Taylor, C. J. Seftor, R. D. McPeters, and P. K. Bhartia, A correction for total ozone mapping spectrometer profile shape errors at high latitude, J. Geophys. Res., 102, 9029-9038, 1997.

World Meteorological Organization (WMO), SPARC/IOC/GAW assessment of trends in the vertical distribution of ozone, edited by N. Harris, R. Hudson, and C. Phillips, SPARC Rep. No. 1, WMO Global Ozone Res. and Monit. Proj., Rep. No. 43, Geneva, 1998a. 
World Meteorological Organization (WMO), JOSIE, edited by H. Smit and D. Kley, Rep. No. 130, WMO Global Ozone Res. and Monit. Proj., Rep. No. TD926, Geneva, 1998b.

Ziemke, J. R., S. Chandra, A. M. Thompson, and D. P. McNamara, Zonal asymmetries in southern hemisphere column ozone: Implications of biomass burning, J. Geophys. Res., 101, 14,421-14,427, 1996.

Ziemke, J. R., S. Chandra, and P. K. Bhartia, Two new methods for deriving tropospheric column ozone from TOMS measurements: The assimilated UARS MLS/HALOE and convective-cloud differential techniques, J. Geophys. Res., 103, 22,115-22,128, 1998.

G. J. R. Coetzee, South African Weather Service, PB X097, Pretoria 0001, South Africa.

M. Fujiwara, Radio Science Center for Space and Atmosphere, Kyoto University, Kyoto, Japan.
B. Hoegger, Swiss Aerological Observatory, Méteo-Suisse, Payerne, Switzerland.

B. J. Johnson, S. J. Oltmans, and H. Vömel, NOAA Climate Monitoring and Diagnostics Laboratory, Boulder, CO 80305, USA.

S. Kawakami and T. Ogawa, NASDA Earth Observations Research Center, Tokyo, Japan.

V. W. J. H. Kirchhoff, INPE Laboratorio Ozonio, São José dos Campos, Brazil

G. Labow, R. D. McPeters, A. M. Thompson, and J. C. Witte, Atmospheric Chemistry and Dynamics Branch, NASA Goddard Space Flight Center, Building 33, Room E417, Mail Code 916, Greenbelt, MD 20771, USA. (anne.m.thompson@nasa.gov)

J. A. Logan, Harvard University, Cambridge, MA 02138, USA.

F. Posny, Université de la Réunion, St.-Denis, Réunion, France.

F. J. Schmidlin, NASA Wallops Flight Facility, Mail Code 972, Wallops Is., VA 23337, USA. 